\title{
Review Article \\ Phytochemicals and Medicinal Properties of Indigenous Tropical Fruits with Potential for Commercial Development
}

\author{
Hock Eng Khoo, ${ }^{1,2}$ Azrina Azlan, ${ }^{1,2,3}$ Kin Weng Kong, ${ }^{4}$ and Amin Ismail ${ }^{1,2,3}$ \\ ${ }^{1}$ Department of Nutrition and Dietetics, Faculty of Medicine and Health Sciences, Universiti Putra Malaysia (UPM), \\ 43400 Serdang, Selangor, Malaysia \\ ${ }^{2}$ Research Centre of Excellence for Nutrition and Non-Communicable Diseases, Faculty of Medicine and Health Sciences, \\ Universiti Putra Malaysia (UPM), 43400 Serdang, Selangor, Malaysia \\ ${ }^{3}$ Laboratory of Halal Science Research, Halal Products Research Institute, Universiti Putra Malaysia (UPM), \\ 43400 Serdang, Selangor, Malaysia \\ ${ }^{4}$ Department of Molecular Medicine, Faculty of Medicine, University of Malaya, 50603 Kuala Lumpur, Malaysia
}

Correspondence should be addressed to Azrina Azlan; azrinaaz@upm.edu.my

Received 28 December 2015; Revised 29 April 2016; Accepted 4 May 2016

Academic Editor: Daniela Rigano

Copyright (C) 2016 Hock Eng Khoo et al. This is an open access article distributed under the Creative Commons Attribution License, which permits unrestricted use, distribution, and reproduction in any medium, provided the original work is properly cited.

\begin{abstract}
Hundreds of fruit-bearing trees are native to Southeast Asia, but many of them are considered as indigenous or underutilized. These species can be categorized as indigenous tropical fruits with potential for commercial development and those possible for commercial development. Many of these fruits are considered as underutilized unless the commercialization is being realized despite the fact that they have the developmental potential. This review discusses seven indigenous tropical fruits from 15 species that have been identified, in which their fruits are having potential for commercial development. As they are not as popular as the commercially available fruits, limited information is found. This paper is the first initiative to provide information on the phytochemicals and potential medicinal uses of these fruits. Phytochemicals detected in these fruits are mainly the phenolic compounds, carotenoids, and other terpenoids. Most of these phytochemicals are potent antioxidants and have corresponded to the free radical scavenging activities and other biological activities of the fruits. The scientific research that covered a broad range of in vitro to in vivo studies on the medicinal potentials of these fruits is also discussed in detail. The current review is an update for researchers to have a better understanding of the species, which simultaneously can provide awareness to enhance their commercial value and promote their utilization for better biodiversity conservation.
\end{abstract}

\section{Introduction}

Southeast Asian countries, including Malaysia, have tropical rainforests with a variety of fruit-bearing trees. These trees are evergreen and growing throughout the year. Many of these trees produce edible fruit for animals living within the scrubs and some of these fruits are even used by the local communities in their traditional medicine [1]. Since centuries ago, human started to cultivate different plant species to harvest their edible fruits as food sources. In the ancient days, cultivation of the fruit-bearing trees for their edible fruits was done only by planting them beside the house or around the housing areas. Hence, the fruits can be easily harvested during the fruiting season. Large-scale farming has been introduced and started in the later years for commercialization of these tropical fruits due to increasing in their market demand.

Today, many of the tropical fruits have been commercialized. These fruits are banana (Musa spp.), durian (Durio zibethinus L.), jackfruit (Artocarpus heterophyllus Lam.), mangosteen (Garcinia mangostana L.), papaya (Carica papaya L.), pineapple (Ananas comosus [L] Merr.), pitaya (Hylocereus spp.), pomelo (Citrus maxima [Burm.] Merr.), rambutan (Nephelium lappaceum L.), and watermelon (Citrullus lanatus [Thunb.] Matsum. \& Nakai). However, in this decade, some indigenous tropical fruits previously unavailable in the market became available in the local markets of Southeast Asia. These include ambarella (Spondias dulcis 
L.), cempedak (Artocarpus integer [Thunb.] Merr.), langsat (Lansium domesticum Corrêa), pulasan (Nephelium mutabile Blume), and salak (Salacca zalacca [Gaertn.] Voss), whereas bambangan (Mangifera pajang Kosterm.), dabai (Canarium odontophyllum Miq.), durian nyekak (Durio kutejensis Hassk. \& Becc.), and some wild bananas (Musa spp.) [2] are found mainly in the Borneo market because they are native to Borneo Island. However, some of these fruits are still collected from their wildly grown trees, and their potential medicinal properties are not well understood.

This review comprehensively discussed the phytochemicals and medicinal properties for 15 species of indigenous tropical fruits. Their common names, as well as the scientific names, are shown in Table 1 . In this review, the 15 species of indigenous tropical fruits are grouped into indigenous tropical fruits with potential for commercial development and indigenous tropical fruits that are possible for commercial development in Southeast Asia, particularly in Malaysia [3]. The indigenous tropical fruit with potential for commercial development are fruits that are frequently consumed by the local communities and readily available in the local markets of Southeast Asia especially during the fruiting season. These fruits, however, are less attractive than the commercially available species. Hence, they are not cultivated in a large-scale plantation or as cash crops. On the other hand, indigenous tropical fruits that are possible for commercial development are those fruits that have lesser popularity than the previous one, and they are only available in part of the tropical regions.

Many of these fruits have high nutritive values but their medicinal properties remain unknown [3]. Thus, more effort is needed to research on these fruit species, especially phytochemicals in the fruits which are necessary for future promotion on their use as food and medicine. In this review, phytochemicals of the selected indigenous tropical fruits are categorized into three major groups: (1) phenolics, (2) carotenoids, and (3) terpenes and terpenoids. These phytochemicals are commonly found in many fruits. Anthocyanins are the compounds that contributed to the attractive color of many fruits, ranging from red to purple, whereas carotenoids give yellow to orange colors to fruit. Carotenoids in fruit are divided into carotenes and xanthophylls [4], whereas phenolic compounds in fruits are phenolic acids and flavonoids [5]. Terpenes and other terpenoids in fruits are mainly the volatile compounds, especially triterpenes [6], and saponin is another member of terpenoids group having both hydrophilic and lipophilic properties.

Since early civilization, various fruits have been traditionally used as folk medicine [7]. Besides the fruit, bark, leaves, stem, root, twig, and sap have been used as ingredients for traditional medicine. These parts have been widely used as folk medicines by locals for treating several diseases, including cough, fever, asthma, diarrhea, indigestion, and skin diseases [8]. In modern medicine, extracts of different parts of the plant including fruit have been further employed for their medicinal benefits, as the antifungal, antimicrobial, antiatherosclerotic, antihypercholesterolemic, antileukemic, anticlastogenic, and antiproliferative agents [9]. Most of the bioactive compounds found in plant extracts are the primary candidates for their medicinal properties. Owing to the limited work that has been done on underutilized species, this review aims to enlighten researchers and international communities on the bioactive components and potential medicinal properties of 15 selected indigenous tropical fruits. Data related to the phytochemicals in these fruits, including phenolic compounds, carotenoids, terpenes, and terpenoids, are obtained from research papers published in international journals and Internet sources (accessed on November 2014 to April 2016).

\section{Indigenous Tropical Fruits with Potential for Commercial Development}

Among hundreds tropical fruits in Malaysia, less than a dozen are categorized as indigenous tropical fruit with potential for commercial development. These fruits are horse mango, Borneo mango, plum mango, African black olive, rose apple, Malay apple, and Indian jujube (Table 1). Plum mango, horse mango, rose apple, Malay apple, and Indian jujube are well known in Peninsular Malaysia, while dabai and bambangan are native to Borneo Island, especially in East Malaysia. The trees of C. odontophyllum (dabai) are also grown in West Indonesia.

These seven indigenous tropical fruits from four different plant families are with commercialization potential in Malaysia. Both Bouea and Mangifera fruits are belonging to the Anacardiaceae family. The other fruits are belonging to the Burseraceae (Canarium), Myrtaceae (Syzygium), and Rhamnaceae (Ziziphus) families. Bouea and Mangifera fruits are closely related because they are from the same family, and the fruits are collectively called as "mango." On the other hand, plum mango, horse mango, and bambangan (Borneo mango) are mango fruits with some similarity in physical appearance. Among the Bouea genus, B. macrophylla (plum mango) is native to Peninsular Malaysia, North Sumatra, and West Java. However, the trees of B. macrophylla are nowadays widely cultivated in Indonesia, Philippines, Thailand, and Mauritius [10]. B. gandaria is a synonym for B. macrophylla, and it is also called as gandaria or setar (Malay name). Alor Setar, the capital city of Kedah, obtained its name from $B$. macrophylla plant. Horse mango or Mangifera foetida is native to Southeast Asia, especially Peninsular Malaysia, Thailand, Sumatra, and the Borneo Island. The fruit of $M$. pajang (bambangan) is an indigenous fruit from Borneo Island [11].

Another interesting indigenous tropical fruit with potential commercial development in Malaysia, especially Sarawak, is dabai. It is known as C. odontophyllum fruit and mainly cultivated in Sarawak, Malaysia. The Semongok Agricultural Research Centre of Sarawak has an industrial collaboration to initiate dabai plantations and enhance dabai product development in the near future. Other than dabai, the fruits of Syzygium jambos (rose apple) and S. malaccense (Malay apple) are the good sources of antioxidants [12]. Eugenia jambos and E. malaccensis are the synonyms for S. jambos and $S$. malaccense, respectively. The key difference between these two fruits is their color: rose apple has a pale yellow appearance with a mixture of pinkish hue, whereas Malay 


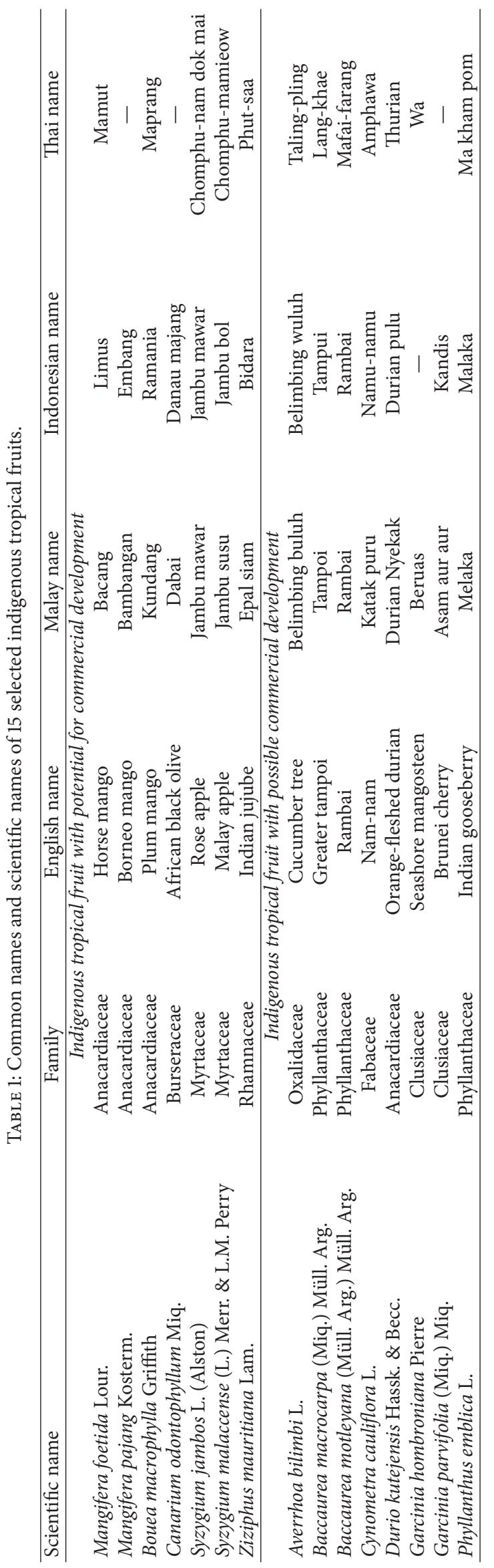


apple is milky in color. Some varieties of $S$. malaccense plant have red colored fruit. The fruit of $Z$. mauritiana is native to Indonesia, India, and China. In Malaysia, the fruit of $Z$. mauritiana is commonly used in culinary practices.

\section{Indigenous Tropical Fruits That Are Possible for Commercial Development}

According to the Department of Agriculture Malaysia, over 370 species of fruit-bearing trees are found in Malaysia [50]. Even though most of these trees are wildly grown, some of them bear fruits with commercial values. In this review, eight indigenous fruits from different genera categorized as fruits that possible for commercial development in Malaysia or Southeast Asia have been discussed. The fruits of Averrhoa bilimbi, Baccaurea macrocarpa, Baccaurea motleyana, Cynometra cauliflora, Durio kutejensis, Garcinia hombroniana, G. parvifolia, and Phyllanthus emblica are categorized in this group. Their common names are tabulated in Table 1. All of these fruits are belonging to different plant families, except Baccaurea and Phyllanthus fruits, which belong to the Phyllanthaceae family.

Out of 2000 species, only certain plant species from Phyllanthaceae are cultivated in the tropical countries. Phyllanthus emblica (also known as Emblica officinalis) is locally known as "Pokok Melaka"; it is another underutilized plant native to Malaysia. The name of Malacca (Melaka) state, a historical city in Malaysia, is originated from the P. emblica trees that are well grown along the riverside. Its fruit is not popular among Malaysians and hence it is only homegrown in some areas of Malaysia. Although P. emblica trees have been planted for the ornamental purpose, the fruit has been reported as a potential source of functional food because it contains a high amount of vitamin C [51]. In India, the fruit of $P$. emblica is traditionally eaten by steeping the sour fruit in turmeric and adding it to salt water to make it palatable [52]. The extract of $P$. emblica fruit has also been used as hair dye [53]. Other fruits of the family Phyllanthaceae are Baccaurea fruits, which include B. macrocarpa (tampoi) and B. motleyana (rambai). These species are widely cultivated on the west coast of Peninsular Malaysia, especially in Perak, a state in Malaysia. Due to the annual fruiting season [54], Baccaurea fruits can be found only in the local markets during the months of peak fruiting period. The trees of B. motleyana are also found in other parts of Southeast Asia, especially Thailand, mainly for fruit cultivation. "Rambai" is the Malay name while "mafai-farang" is the Thai name of $B$. motleyana fruit (Table 1).

A. bilimbi, also known as "belimbing buluh" or cucumber tree, is native to Malaysia and Indonesia. It has been cultivated in Southeast Asia. In India, the trees of $A$. bilimbi are planted in the home gardens. A. bilimbi fruit is lesser popular for consumption than the commercially known star fruit $(A$. carambola). However, it is traditionally used as medicine for curing several diseases, including cardiovascular diseases [55]. Besides vitamins and minerals, the fruit of A. bilimbi also contains flavonoids and triterpenoids that contribute to its beneficial health properties [56]. Besides A. bilimbi,
C. cauliflora is another homegrown fruit-bearing tree that is found primarily in rural areas of Peninsular Malaysia. Its fruit is locally called as "nam-nam." The fruit of $C$. cauliflora has savory taste and can be consumed as fruit salad.

G. hombroniana is another plant native to Malaysia. The tree bears fruit called "seashore mangosteen" [27]. Another species of Garcinia, G. parvifolia, is also one of the indigenous tropical plants [57]. Garcinia fruits contain xanthones, flavones, and triterpenoids as the bioactive phytochemicals besides the leaves and twig of Garcinia trees [58]. D. kutejensis is another type of durian plant. The color of its flesh is orange-reddish due to the high amount of carotenoids. It is native to Borneo region, called as durian nyekak in East Malaysia. It has the taste and texture similar to the fruit of common D. zibethinus. The fruits of D. zibethinus or commercial durians are the most famous fruits in Malaysia and Thailand. However, the fruit of D. kutejensis is not available in Peninsular Malaysia owing to the fact that the trees of this fruit are native to Java and Borneo Islands [59]. D. kutejensis is a wildly grown species, and its fruits are collected by the indigenous people of Borneo Island (including Sabah and Sarawak) for their own consumption or selling in the local market. Therefore, D. kutejensis fruit is considered underutilized in Malaysia. Hence, in Peninsular Malaysia, the fruit of $D$. kutejensis cannot be found in the local markets throughout the year.

\section{Industrial Applications of Indigenous Tropical Fruits and Their Potential as Commercial Products}

In Southeast Asia, actually many indigenous tropical fruits have potential to be commercialized. In comparison between Malaysia and Thailand, many of the Malaysian indigenous fruits are underexploited. The underutilized indigenous fruits from Peninsular Malaysia have lesser commercial potential as compared with the underutilized indigenous fruits from East Malaysia (Borneo region). Dabai (C. odontophyllum), bambangan (M. pajang), and some wild banana (Musa spp.) from Borneo are the good examples where these fruits have been developed into different commercial products for local uses.

Dabai is an indigenous tropical fruit that is almost similar to olive. The oil extracted from the pulp of dabai demonstrated some possible health benefits [60]. In Sarawak (East Malaysia), the edible part of dabai has been incorporated into local cuisines such as fried rice, omelet, and being developed into the form of sauce or paste as an ingredient for cooking. Bambangan, as one of the big mangoes in the world [61], has also been used in cooking and as dessert. Bambangan juice is commonly consumed by the local people of Sabah (East Malaysia). In Sabah and Kalimantan, bambangan pickled can be seen being sold in the local markets, whereas bambangan peel is used as a raw ingredient for some local dishes. Besides dabai and bambangan, bananas (Musa spp.) from Borneo region are processed into banana chips.

On the other hand, in Peninsular Malaysia, bacang ( $M$. foetida), kundang (B. macrophylla), and jambu (Syzygium 
<smiles>O=c1c(O)c(-c2ccc(O)c(O)c2)oc2cc(O)cc(O)c12</smiles><smiles>O=C(O)c1cc(O)c(O)c(O)c1</smiles>

Gallic acid<smiles>Oc1cc(O)c2cc(O)c(-c3ccc(O)c(O)c3)[o+]c2c1</smiles>

Cyanidin

FIGURE 1: Major phenolic compounds in plant.

spp.) are those fruits that are having the potential for development into commercial products, such as canned fruit, pickles, and fruit juices. Although bidara ( $Z$. mauritiana) is one of the commercialized fruits in India [70], this fruit is not commonly consumed by Malaysian. The fruit is only freshly eaten or preserved as pickle by Malay community.

\section{Phytochemicals in 15 Selected Indigenous Tropical Fruits}

5.1. Phenolic Compounds. Phenolic compounds are the largest group of phytochemicals and are widely distributed throughout the plant kingdom. Phenols, as the major bioactive substances in fruits, play a vital role as antioxidant. The major phenolic compounds in plants are shown in Figure 1. Phenolic compounds are good antioxidants found in the flesh of fruits including phenolic acids and flavonoids, whereas flavonoids and lignans are found in the seeds or kernel [71]. Among the phenolic acids, gallic acid is the major component of plant. Each fruit has, at least, a few major phenolic compounds. In addition to fruit, catechin is one of the main flavonoids found in leaves. Since phenolics are potent antioxidants, increased consumption of a mixture of fruits daily should be able to provide an adequate phenolic antioxidant. Thus, proper knowledge concerning identity and amount of phenolics in indigenous tropical fruits helps to promote the usage of these underutilized tropical fruits for their functional benefits.

Total phenolic content (TPC) is one of the most popular indicators for estimation of phenolic antioxidants in fruit. Determination of TPC is straightforward and easy to perform using Folin-Ciocalteu reagent and usually expressed as gallic acid equivalent (GAE) (Table 2). Based on previous literature, B. macrophylla fruits have not been determined for TPC. Table 2 also depicts the phenolic compounds identified and quantified in selected indigenous tropical fruits. Among the indigenous tropical fruits with potential for commercial development, S. malaccense fruit has the least TPC, whereas the other fruits have moderate to high TPC. TPCs of $M$. foetida fruit extracts ranged from 122.8 to $199.8 \mathrm{mg} \mathrm{GAE} / 100 \mathrm{~g}$ of edible portion (EP) [10]. However, a wide range of total phenolics determined in the same type of fruit could be due to the different methods used, as well as the fruit variety and geographical distribution [12].

Among the indigenous tropical fruits, flavonoids are the major antioxidants found in these fruits. As shown in Table 2, a few flavonoids have been identified in C. odontophyllum fruit (dabai), and some unknown flavonoids were detected in dabai pulp [24]. Due to the dark purple color of dabai peel, anthocyanins should be the major phenolics in its peel. Chew et al. [23] have reported different types of anthocyanins that were detected in the dabai peel, such as cyanidin glucoside, malvidin glucoside, and peonidin glucoside. Anthocyanins were also found in the fruits of $S$. malaccense and A. bilimbi. Reynertson et al. [43] reported as much as $0.02 \mu \mathrm{g} / \mathrm{g}$ of cyanidin-3-glucoside that was determined in the peel of dried S. malaccense fruit. The peel might also contain carotenoids and betacyanins because it is red in color. Moreover, a nonpurple colored A. bilimbi fruit exhibited a high concentration of total anthocyanins $(47.36 \mathrm{mg} / 100 \mathrm{~g}$ fresh weight) [18]. However, total anthocyanin content (TAC) determined in the purple colored extract of defatted C. odontophyllum fruit peel was less than $40 \mathrm{mg} / 100 \mathrm{~g}$ dry weight (DW) [24]. The nonpurple colored extract of $A$. bilimbi could have a low TAC because anthocyanins are red-purplish color pigments. The difference could have been due to the use of colorimetric method through $\mathrm{pH}$ differential that resulted in an overestimation of TAC.

Among the fruits that belong to Anacardiaceae family, mangiferin is the primary bioactive phenolic compound in mango ( $M$. indica). Mangiferin is commonly detected in 


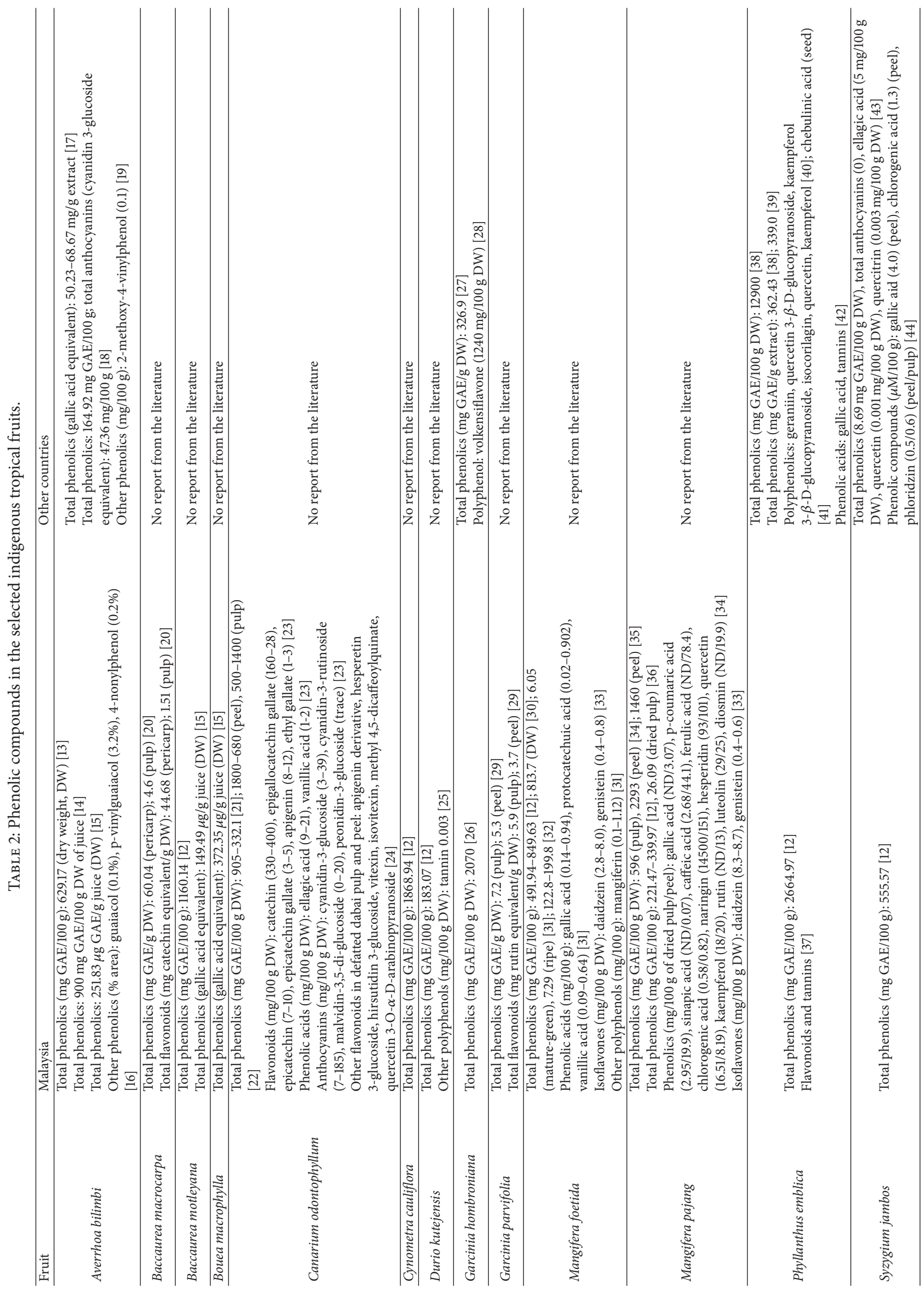




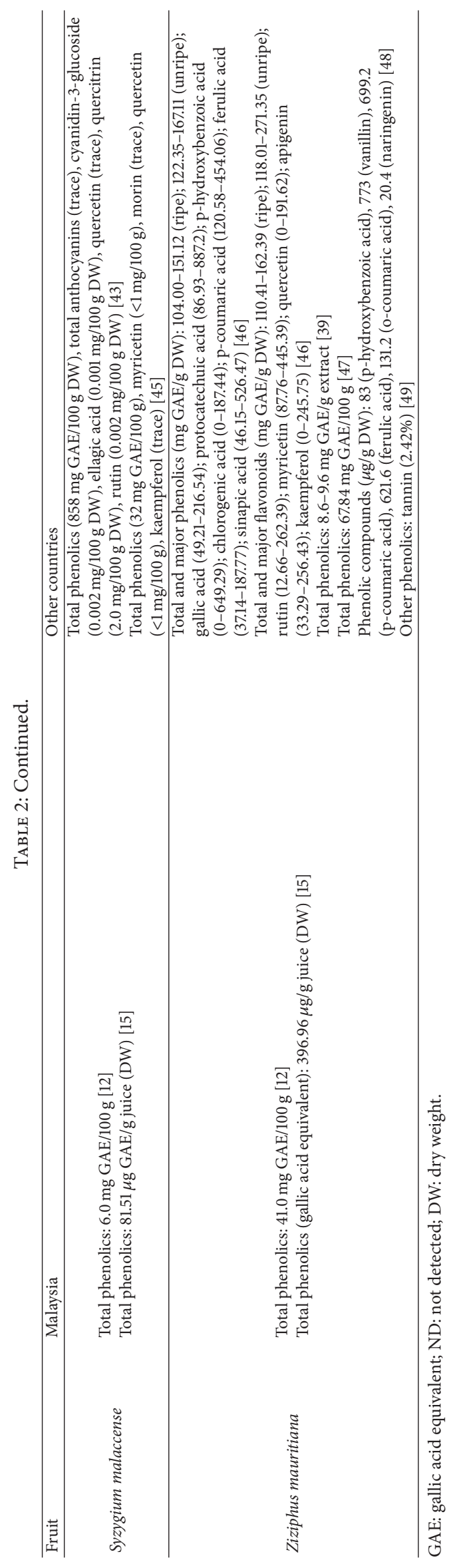




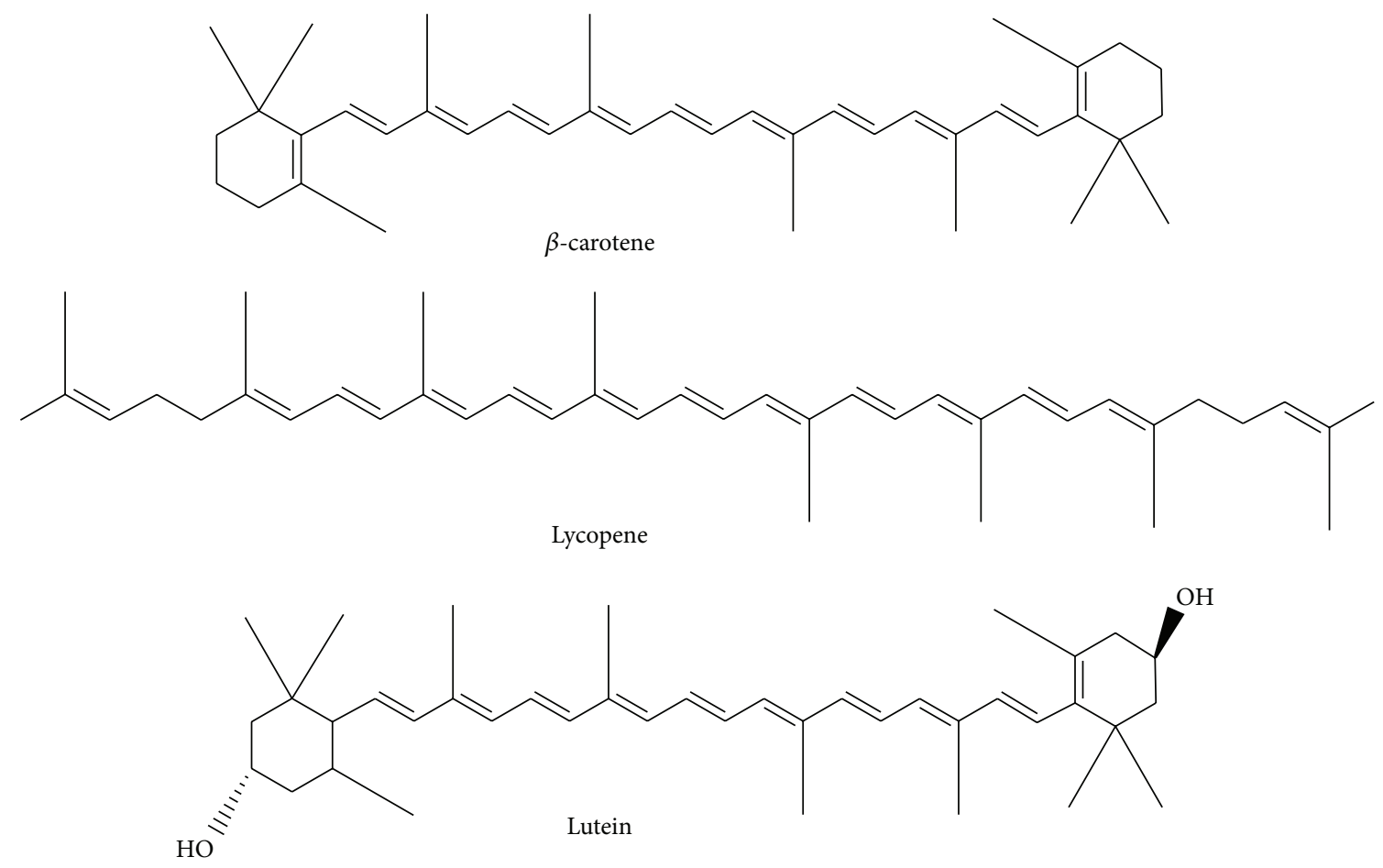

FIgURE 2: Major carotenoids in plant.

other Mangifera fruits [31]. Due to its sour taste, the fruits could also contain various types of phenolic acids. Gallic acid, protocatechuic acid, and vanillic acid are the major phenolic acids in $M$. foetida fruit [31]. Chlorogenic acid, ellagic acid, and gallic acid are also detected in Syzygium fruits (Table 2). While applying HPLC for determination of phenolic compounds, isoflavones were detected in some Mangifera fruits [33], where daidzein is the major isoflavone detected. Besides that, the sour taste of Syzygium fruits also indicates a potentially high level of phenolic acids, and ascorbic acid can be obtained from the fruits. A few studies have determined the polyphenolic compounds in the fruit of $Z$. mauritiana. Due to the variation in geographical distribution, fruit maturity, and variety, the TPCs in Z. mauritiana fruit ranged from 1.13 to $328.65 \mathrm{mg} / 100 \mathrm{~g} \mathrm{EP}$ (Table 2). Besides that, $2.42 \%$ of tannin was also found in the fruit of $Z$. mauritiana [49].

Among hundreds of types of flavonoids, quercetin is a bioactive flavonoid isolated from the fruit of $P$. emblica [72]. Besides quercetin, geraniin, quercetin 3- $\beta$-D-glucopyranoside, kaempferol 3- $\beta$-D-glucopyranoside, isocorilagin, and kaempferol were detected in P. emblica fruit (Table 2). The edible part of $P$. emblica has higher TPC $(2664.97 \mathrm{mg}$ GAE/100 g) than most of the other indigenous underutilized fruits reported [12]. The high TPC in this fruit might be due to the high concentration of vitamin C. Ascorbic acid might have reacted with the Folin-Ciocalteu reagent, hence causing a possibility in overestimation of TPC. The high tannin content in P. emblica fruit is also very useful for Indian communities because the extract has been used as dye or ink [38].
To date, only a very limited information on phenolic compounds is available for the scientific community, especially phenolic compounds in the fruits of Baccaurea, Cynometra, and Garcinia. Besides that, volkensiflavone is one of the potential flavonoids in G. hombroniana fruit [28], and garcinidon $\mathrm{A}$ has been discovered in the peel of G. parvifolia [73]. D. kutejensis fruit also contained $0.03 \mu \mathrm{g}$ of tannin in one gram of dried fruit [25].

5.2. Carotenoids. Among the plant phytochemicals, carotenoids are classified as terpenoids. The compounds are found abundantly in yellow to orange- and orange to red-colored fruits. Carotenoids are grouped into carotenes and xanthophylls. In nature, $\beta$-carotene is the most abundant type of carotene, while lycopene is the primary phytochemical in orange-red colored fruits. Among the xanthophylls, lutein is typically detected in green leafy vegetables. However, some fruits also contain lutein [4]. Figure 2 shows the major types of carotenoid in fruit.

Among the carotenes, all-trans $\beta$-carotene is the most common type of carotenoid found in plant because it is part of the antioxidant defense system at cellular level of a plant. Some green-colored fruits may contain a high amount of carotenoid because the yellow-orange-colored carotenoid pigments are masked by chlorophylls [88]. The intake of carotenoids from various plant sources is thought to be able to maintain good health. In this review, different carotenoids and their concentrations in the selected indigenous tropical fruits are shown in Table 3 . 


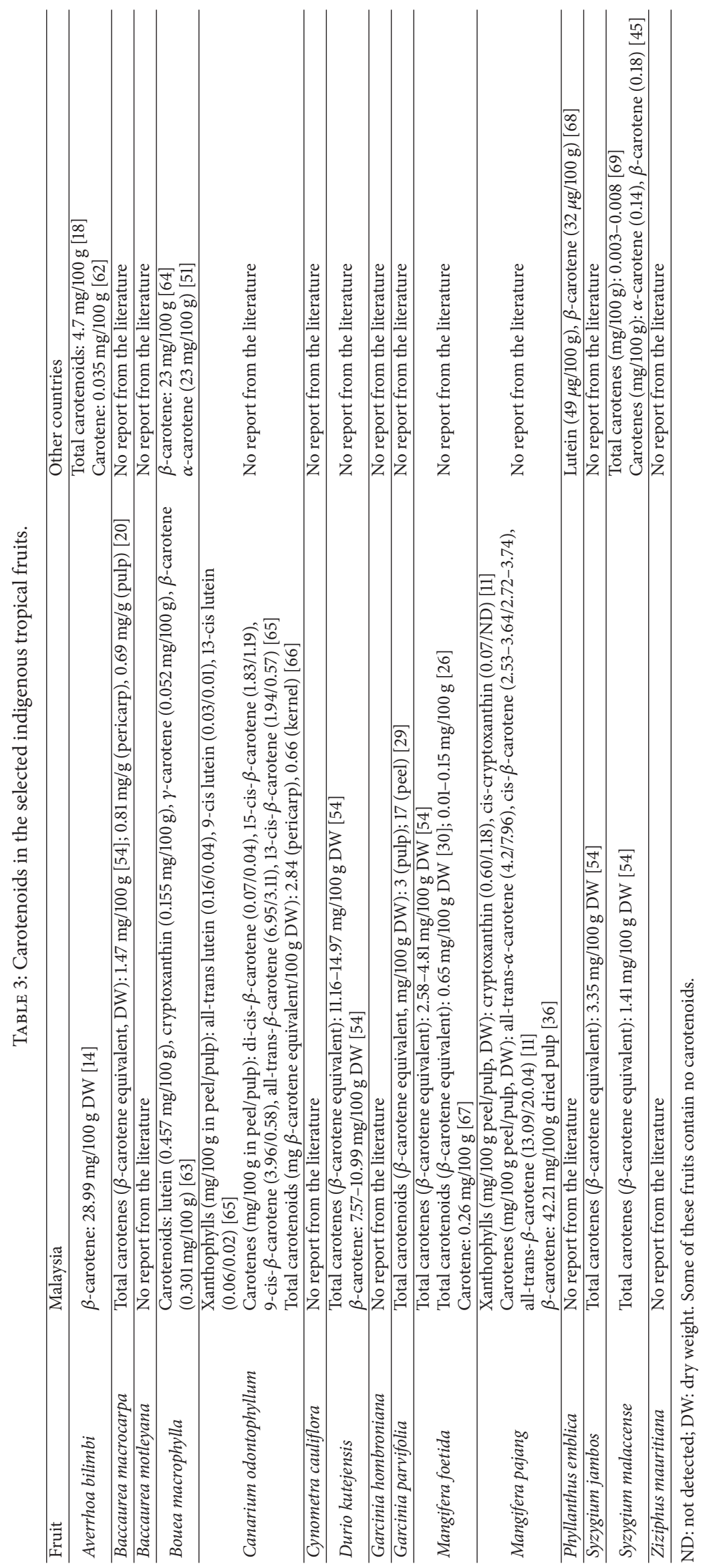


Among the fruits, yellow to orange-colored fruits have high $\beta$-carotene contents, whereas lycopene is the orangered color pigment. Carotenoids contents in some commercialized fruits and vegetables have been reported by Khoo et al. [4]. However, carotenoid contents in other indigenous tropical fruits remain unknown. Many of the indigenous fruits possible for commercial development do not contain any carotenoid. Whitish-colored fruits have little or trace amount of carotenoids, especially the endocarp. No study has been performed to determine the carotenoid contents of B. motleyana, C. cauliflora, G. hombroniana, and $Z$. mauritiana fruits. It is possibly due to the low concentrations of carotenoid in these fruits.

As previously reported, the fruit of $B$. macrocarpa (tampoi) contains carotenoids. However, $\beta$-carotene (a major carotenoid) was not detected in tampoi [53]. There is a broad range of total carotenoid contents found in some of the indigenous tropical fruits (0.003-29 mg/100 g DW) (Table 3). For example, the different varieties of pumpkin have total carotenoids ranging between 0.06 and $14.9 \mathrm{mg} \beta$-carotene per $100 \mathrm{~g}$ fresh weight [4].

Based on the previous study, the total carotenoid content (TCC) of horse mango ( $M$. foetida) was ranged from 96.5 to $153.0 \mu \mathrm{g} \beta$-carotene equivalent (BCE)/100 g EP [10]. In durian nyekak (D. kutejensis), the TCC was $11.16-14.97 \mathrm{mg}$ $\mathrm{BCE} / 100 \mathrm{~g} \mathrm{DW}$ [54]. Although some of the indigenous tropical fruits have a moderate level of TCC (Table 3), the cucumber tree (A. bilimbi) was found to have a higher $\beta$ carotene content $(28.99 \mathrm{mg} / 100 \mathrm{~g}$ dry weight) than the other indigenous tropical fruits [59]. Besides that, P. emblica only has $0.01 \mathrm{mg}$ of $\beta$-carotene in the fruit pulp (per $100 \mathrm{~g}$ edible pulp) [50].

5.3. Terpene and Terpenoids. Monoterpenes, diterpenes, triterpenes, and sesquiterpenes are some of the terpenes discussed in this review. Terpenoid is a vast and diverse class of natural occurring organic chemicals related to terpene [89]. Most of the terpenoids including saponins are possible antioxidants [90]. Besides antioxidant activity, saponins have several health benefits [91]. Among the terpenes and terpenoids, some are volatile compounds found in plants. Geraniol, limonene, linalool, and pinene are some of the volatile components detected in fruit samples (Figure 3). Terpenes, mainly sesquiterpenes, have been identified in the root, bark, flowers, and leaves of plants [92]. Only a few terpenes have been discovered in fruits. Although many studies have been performed on volatile terpenes in essential oils of plants, most of the studies analyzed the other parts of the plant rather than the fruit. From our literature search, a minimum of 20 volatile components including terpenes were found in different parts of the plant. Little information on terpenes and terpenoids content in fruit is available for the scientific community, especially the underutilized and indigenous tropical fruits.

It can be observed in Table 4 that some indigenous tropical fruits with potential for commercial development are well studied for terpenes and terpenoids contents, but not for the fruit of $Z$. mauritiana. Umaru et al. reported that Indian
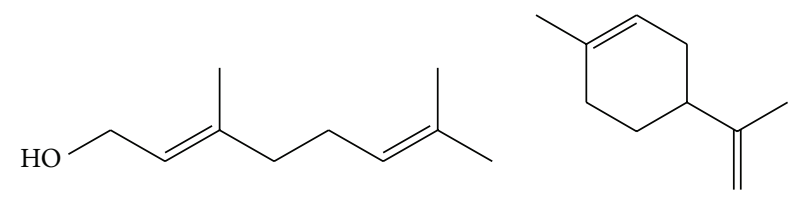

Geraniol

Limonene
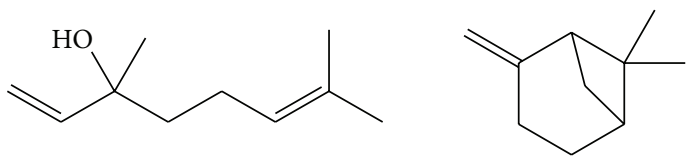

Linalool

Pinene

FIGURE 3: Major volatile terpenoids detected in fruit.

jujube (Z. mauritiana) has $7.13 \%$ saponin [49]. The terpenes and terpenoids contents in some of these indigenous tropical fruits have not been determined elsewhere besides Malaysia. For the indigenous tropical fruit with possible commercial development, no study has reported terpenes and terpenoids contents in these tropical fruits, except for A. bilimbi, B. motleyana, G. hombroniana, and P. emblica fruits. Also, information on terpenes and terpenoids in fruits of B. macrocarpa, C. cauliflora, D. kutejensis, G. parvifolia, and Z. mauritiana are limited due to lacking of published data available for referencing. Moreover, terpenes and terpenoids in the fruits of A. bilimbi, G. hombroniana, and P. emblica have been determined by researchers from several known countries such as Malaysia and Thailand (Table 4).

Terpenes and terpenoids are natural phytochemicals identified in plants. Fruit contains some terpenes, such as monoterpene, triterpene, and sesquiterpene. For the indigenous tropical fruits with potential for commercial development, such as B. macrophylla, M. foetida, M. pajang, S. jambos, and $S$. malaccense, some terpenes and terpenoids have been identified in the extracted essential oil of these fruits (Table 4). Besides carotenoids, saponin is one of the terpenoids found in the defatted dabai [24].

Among the indigenous tropical fruits possible for commercial development, $B$. motleyana and $P$. emblica fruits have low concentrations of terpenes, terpenoids, and saponins. Wong et al. reported that terpenes are the minor components in the essential oil of rambai (B. motleyana) [74]. Saponin is one of the members of the triterpenoid group [93]. It has been discovered in Indian gooseberry ( $P$. emblica) [37]. In Cuba, a study has identified $\alpha$-pinene, p-cymene (0.02), limonene, 1,8-cineole, $\gamma$-terpinene, terpinolene, $\alpha$-terpineol, $\delta$-cadinene, $\alpha$-calacorene, and other volatile components in the essential oil of $A$. bilimbi fruit [19]. These compounds are monoterpenes and sesquiterpenes commonly found in plants. The essential oil of $P$. emblica fruit contains $\beta$ caryophyllene and $\beta$-bourbonene as the major terpenes [80]. Besides that, the fruit of $G$. hombroniana has two novel triterpenes (17,14-friedolanostanes and lanostanes) [76]. Terpenoids, such as saponins, are the important phytochemical constituents in combating the infectious diseases and terpenoids are primarily discovered as the potent antimicrobial 


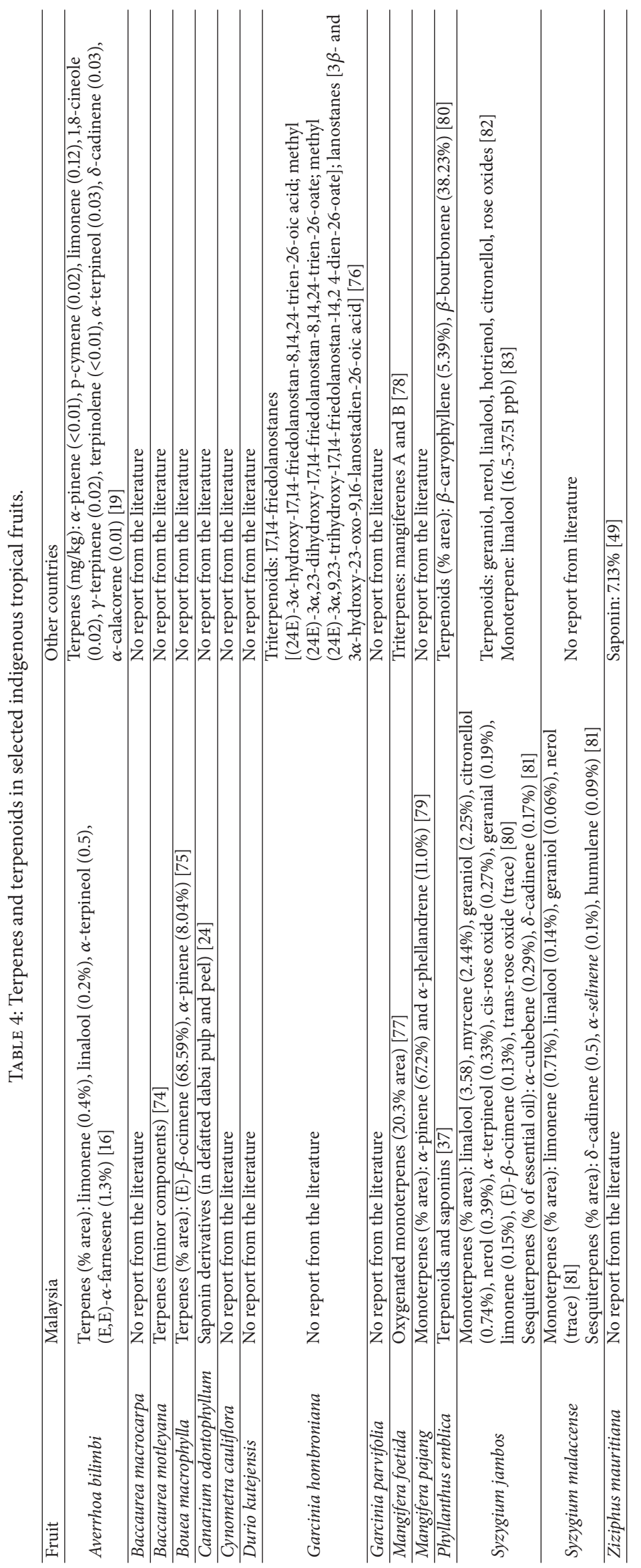


TABLE 5: The uses of selected indigenous tropical fruits as food and folk medicine.

\begin{tabular}{|c|c|c|c|}
\hline Number & Fruit & As food & Folk medicine \\
\hline 1 & Averrhoa bilimbi [84] & $\begin{array}{l}\text { Freshly eaten as salad or pickle, and used } \\
\text { in cooking dishes (whole ripe fruit) }\end{array}$ & $\begin{array}{l}\text { Ripe fruits combined with pepper for } \\
\text { inducing sweating; pickled bilimbi is } \\
\text { smeared all over the body to hasten } \\
\text { recovery after a fever; fruit conserves for } \\
\text { treatment of coughs, beriberi, and } \\
\text { biliousness; fruit syrup for reducing fever } \\
\text { and inflammation and to alleviate } \\
\text { internal hemorrhoids }\end{array}$ \\
\hline 2 & Baccaurea macrocarpa & Freshly eaten (ripe flesh) & No report on usage as folk medicine \\
\hline 3 & Baccaurea motleyana [84] & $\begin{array}{l}\text { Freshly eaten and made into jam (ripe } \\
\text { flesh) }\end{array}$ & No report on usage as folk medicine \\
\hline 4 & Bouea macrophylla [84] & $\begin{array}{l}\text { Freshly eaten as salad or pickle, and used } \\
\text { in cooking dishes (whole ripe fruit) }\end{array}$ & No report on usage as folk medicine \\
\hline 5 & $\begin{array}{c}\text { Canarium odontophyllum } \\
{[84]}\end{array}$ & $\begin{array}{l}\text { Freshly eaten and as salad, made into jam, } \\
\text { and used in cooking dishes (ripe flesh) }\end{array}$ & No report on usage as folk medicine \\
\hline 6 & Cynometra cauliflora & $\begin{array}{l}\text { Freshly eaten as salad and used in } \\
\text { cooking dishes (ripe flesh) }\end{array}$ & No report on usage as folk medicine \\
\hline 7 & Durio kutejensis [84] & Freshly eaten (ripe flesh) & No report on usage as folk medicine \\
\hline 8 & Garcinia hombroniana & Freshly eaten (ripe flesh) & No report on usage as folk medicine \\
\hline 9 & Garcinia parvifolia & $\begin{array}{l}\text { Freshly eaten (ripe flesh), as pickle and } \\
\text { used in cooking dishes (unripe flesh) }\end{array}$ & No report on usage as folk medicine \\
\hline 10 & Mangifera foetida [84] & $\begin{array}{l}\text { Freshly eaten (ripe flesh), as pickle and } \\
\text { used in cooking dishes (unripe flesh) }\end{array}$ & $\begin{array}{l}\text { Seeds used against trichophytosis, } \\
\text { scabies, and eczema }\end{array}$ \\
\hline 11 & Mangifera pajang [84] & $\begin{array}{l}\text { Freshly eaten (ripe flesh), as pickle and } \\
\text { used in cooking dishes (unripe flesh) }\end{array}$ & No report on usage as folk medicine \\
\hline 12 & Phyllanthus emblica [85] & $\begin{array}{l}\text { Freshly eaten (ripe flesh), as pickle and } \\
\text { used in cooking dishes (unripe flesh) }\end{array}$ & $\begin{array}{l}\text { Fruit for treating cough and asthma, and } \\
\text { several other health complications }\end{array}$ \\
\hline 13 & Syzygium jambos [86] & $\begin{array}{l}\text { Freshly eaten, made into jam and served } \\
\text { as dessert (whole ripe fruit) }\end{array}$ & $\begin{array}{l}\text { Ripe fruit is used as a tonic for brain and } \\
\text { liver and as a diuretic; seeds for treatment } \\
\text { of diarrhea, dysentery, and catarrh }\end{array}$ \\
\hline 14 & Syzygium malaccense [86] & $\begin{array}{l}\text { Freshly eaten (whole ripe fruit), as pickle } \\
\text { and used in cooking dishes (unripe fruit) }\end{array}$ & Fruit decoction as a febrifuge \\
\hline 15 & $\begin{array}{l}\text { Ziziphus mauritiana } \\
{[86,87]}\end{array}$ & $\begin{array}{l}\text { Freshly eaten as salad or pickle, and used } \\
\text { in cooking dishes (whole ripe fruit) }\end{array}$ & $\begin{array}{l}\text { Ripen fruit for treatment of sore throat } \\
\text { and cough; seed for treatment of diarrhea } \\
\text { and weakness of stomach }\end{array}$ \\
\hline
\end{tabular}

agents. Antimicrobial effects of the essential oils of many fruits have been reported by Nychas [94].

\section{Medicinal Properties of 15 Indigenous Tropical Fruits}

Fruits are commonly consumed for their nutrients, and some fruits are used as medicine. The medicinal properties of fruits are closely related to their available phytochemicals, as well as antioxidants. Many of the indigenous fruits have been traditionally used as folk medicine. These fruits contain phytochemical antioxidants that can prevent, treat, and cure various types of diseases. Many phytochemicals such as carotenoids, tannic acids, triterpenes, and some flavonoids are free radical scavengers that can contribute to the suppression of oxidative stress and anti-inflammatory effect in the human body [95]. The details on the applications of 15 selected indigenous fruits as food and as folk medicine are tabulated in Table 5. Additionally, the medicinal values of these indigenous tropical fruits reported by previous scientific reports are listed in Table 6. Among the 15 indigenous tropical fruits, the flesh of five fruits are not scientifically determined for their medicinal values, except for antioxidant activities. The other fruits have been studied for antimicrobial effects (including fungal) and several protective effects against chronic diseases. Among the scientific evidence shown in previous literature, most of the experiments are mainly focused on in vitro and animal models. Limited studies on human intervention trials allow researchers or scientists to study the potential health effects of these underutilized tropical fruits using human models in the future.

In this review, the medicinal properties of the selected underutilized tropical fruits are discussed. The protective effects of these fruits against several diseases are shown, either as folk medicines or with scientific evidence. Overall, among the 15 indigenous tropical fruits, the fruits of 


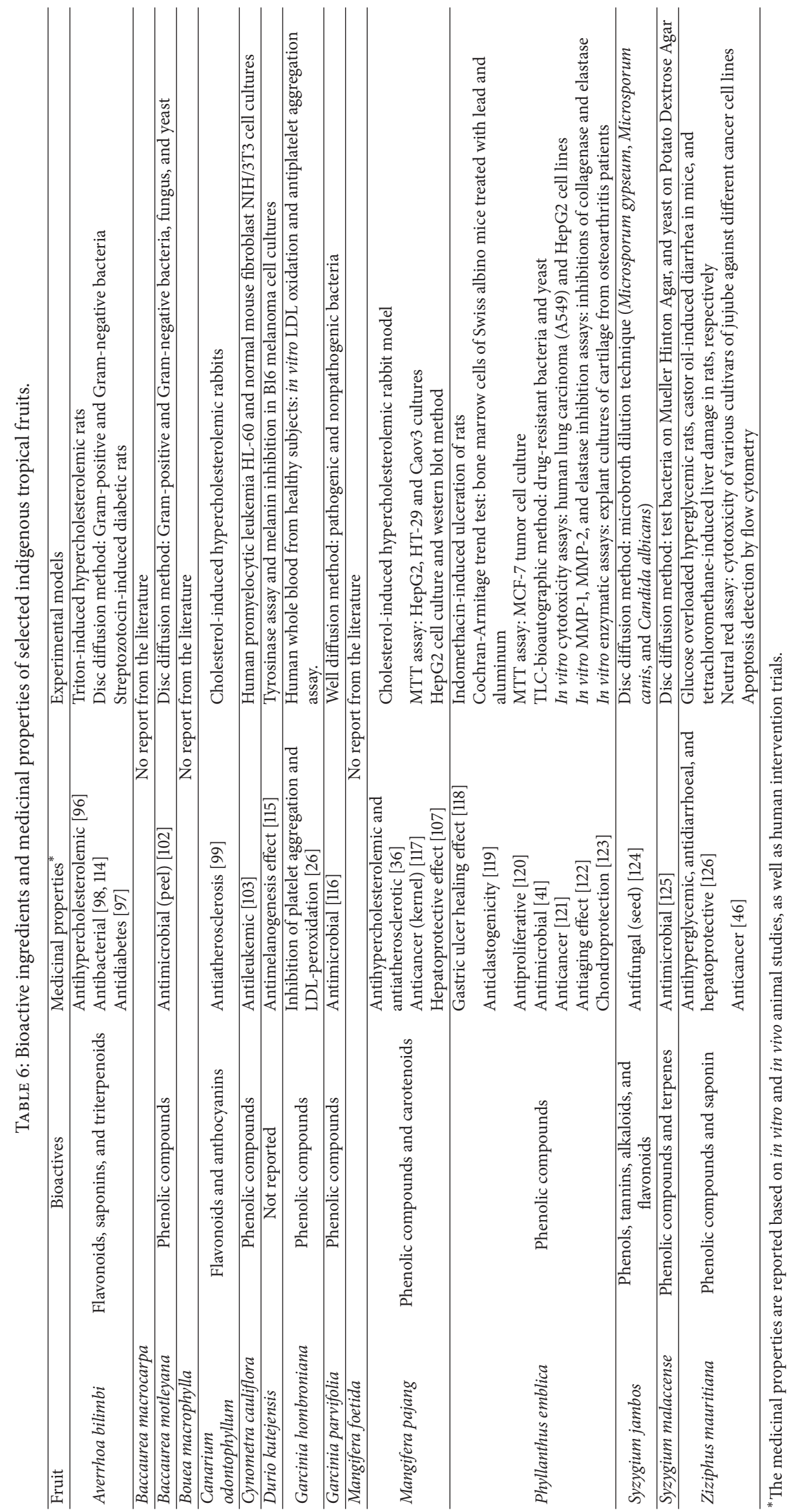


B. macrocarpa, B. motleyana, B. macrophylla, C. odontophyllum, C. cauliflora, D. kutejensis, G. hombroniana, G. parvifolia, and $M$. pajang have not been reported for their use as folk medicine (Table 5). However, three out of these 15 indigenous tropical fruits have not been scientifically determined for their medicinal properties and potential health benefits. These fruits are B. macrocarpa, B. macrophylla, and M. foetida (Table 6).

Among hundreds of fruit species, the fruit of $A$. bilimbi (cucumber tree) is one of the potential sources of antioxidant that offers health benefits. According to Ambili et al., the extracts of $A$. bilimbi exhibited the cholesterol-lowering potential in rats [96]. The water extract of $A$. bilimbi fruit $(0.8 \mathrm{mg} / \mathrm{kg}$ body weight, BW) also improved lipid profile in Triton-induced hypercholesterolemia in rats [96]. Other than that, the active fraction of the water extract at a dose of $0.3 \mathrm{mg} / \mathrm{kg}$ BW possessed an optimum antihypercholesterolemic activity. The fruit $(125 \mathrm{mg} / \mathrm{kg} \mathrm{BW})$ and its water extract $(50 \mathrm{mg} / \mathrm{kg} \mathrm{BW})$ also effectively improved the lipid profile of the rats fed with high-fat diet.

Another study reported that the fruit of A. bilimbi has antidiabetic effect studied using streptozotocin-induced diabetic rats [97]. The flavonoids, carotenoids, and terpenes could be the potent bioactive compounds in $A$. bilimbi fruits that provide the antidiabetic effect. Besides that, this fruit is also reported as an active antimicrobial agent. Chloroform and methanolic extracts of this fruit (bilimbi) were reported to have good inhibitory activities on several types of bacteria, such as Aeromonas hydrophila, Escherichia coli, Klebsiella pneumoniae, Saccharomyces cerevisiae, Staphylococcus aureus, Streptococcus agalactiae, and Bacillus subtilis [98]. Hence, this fruit has been used in folk medicine for easing whooping cough [85]. The scientific evidence for the role of phytochemicals in A. bilimbi fruit extract as health-promoting agents is inadequate. Most of the studies focused only on in vitro and animal models. Up to date, there is no human-based scientific evidence to support its use in the prevention of such diseases.

Flavonoids and anthocyanins in dabai fruit (C. odontophyllum) are the potent antioxidants. The defatted dabai extract $(5 \%)$ was shown to significantly reduce the levels of total cholesterol and low-density lipoprotein-cholesterol in rabbits supplemented with high-cholesterol diet for eight weeks as compared to the control group [99]. Besides that, rabbits fed a high-cholesterol diet and defatted dabai pulp have a significant increment in high-density lipoprotein level [100]. The severity of atherosclerotic plaques in the high-cholesterol diet rabbit group that supplemented with defatted dabai extracts was also reduced compared to the control group. Therefore, the fruit extract of defatted dabai can be considered as a new source of nutraceutical due to its antiatherosclerotic properties. However, no human-based study has been performed to prove the cholesterol-lowering effect of the defatted dabai extract. Human intervention trial is recommended for future study to test the efficacy of defatted dabai parts because dabai is one of the underutilized fruits highly potent to be commercialized.

There are other medicinal uses which were found on D. kutejensis, but it may possess some anti-inflammatory properties as it has many similarities to the D. zibethinus, where the methanolic extracts of $D$. zibethinus fruit were reported to have anti-inflammatory effects [101]. The extract of $B$. motleyana peel possessed antimicrobial activities since it inhibited the growth of $S$. aureus, B. cereus, B. subtilis, E. coli, Pseudomonas aeruginosa, and Proteus vulgaris [102]. The fruit of Cynometra cauliflora possesses antiproliferative activity by inhibition of cytotoxic effect to human promyelocytic leukemia HL-60 cells [103].

Generally, most of the plants from genus Garcinia have medicinal effects [104]. In Southeast Asia, only a few studies were reported on the potential medicinal properties of underutilized Garcinia fruits. The fruit extract of G. hombroniana inhibited in vitro lipid peroxidation and had antiplatelet activities [26]. Other than the fruits, Kapadia and Rao also report antimicrobial effects of Garcinia plants towards bacteria, fungus, and other parasites [57]. The stems and leaves of three Garcinia plants indicate platelet-activating factor antagonist activity [105]. Among the three Garcinia plants, the leaves of $G$. hombroniana (seashore mangosteen) have higher microbial inhibition activity (46.3\%) than the leaves and stems of G. cowa (cowa) and G. dulcis (mundu). The main bioactive compound in the leaves that possess this antimicrobial effect is reported as garcihombronane [57].

Mangifera fruit, also known as mango, is traditionally used for its medicinal properties. The kernel of $M$. pajang (Borneo mango) has an anticancer effect [106], and the fruit extract was found to possess hepatoprotective effects [107]. Ibrahim also reported the antiatherosclerotic and antihypercholesterolemic effects of fruit juice powder of $M$. pajang tested using New Zealand white rabbits [36]. Then, a human clinical trial was carried out to verify the efficacy of M. pajang fruit juice which also demonstrated a promising effect. Healthy subjects supplemented with $M$. pajang fruit juice showed better blood lipid parameters compared to the placebo group [108]. The antihypercholesterolemic effect of $M$. pajang fruit juice could be due to the antioxidative effect of polyphenolics, vitamin $C$, and $\beta$-carotene in the juice. A 12 weeks, double-blind, placebo-controlled clinical trial also confirmed that antioxidants $(24 \mathrm{mg} \beta$-carotene B, $1000 \mathrm{mg}$ vitamin C, $800 \mathrm{IU}$ vitamin E) supplementation significantly increased the plasma high-density lipoproteincholesterol in 45 coronary artery disease patients [109]. Both studies have proven that antioxidant supplementation helped in improving plasma lipid profile.

In addition to $M$. pajang fruit, $M$. foetida fruit pulp (without peel) also demonstrated antioxidant activity [30]. On the other hand, the leaf extracts of $M$. foetida have an antimicrobial activity for $S$. aureus, but not for $E$. coli, S. cerevisiae, and Fusarium oxysporum [110]. Besides these findings, other medicinal effect has not been determined for M. foetida (horse mango) fruit, except for its antioxidants in the inhibition of oxidative stress [111].

Emblic (P. emblica) fruit, also called as Indian gooseberry, is traditionally known for its medicinal value for treating cough and asthma [85]. The fruit is traditionally used in India for the treatment of several health complications, such as diarrhea, dysentery, anemia, jaundice, and cough [112]. The fruit is also rich in antioxidant. Liu et al. reported that phenolic compounds extracted from emblic fruits were 
highly correlated with their antioxidant activities [40]. Various parts of $P$. emblica plant have also been used as Indian Ayurvedic medicine. Besides that, phytochemicals in the plant parts are well known for their medicinal values, such as antidiabetic, antibacterial, antiulcerogenic, antiproliferative, and hypolipidemic effects [113].

A study on the healing activity of ethanolic extract of emblic fruit ( $P$. emblica) has shown some positive results, where the rats were induced with indomethacin $(30 \mathrm{mg} / \mathrm{kg}$ BW, oral intubation) [118]. The results showed that the extract $(100 \mathrm{mg} / \mathrm{kg} \mathrm{BW})$ of this fruit had significantly reduced the lipid peroxidation parameters (MDA, carbonyl, total DNA, SOD, and CAT), ulcer index (3.8), and DNA damage induced by indomethacin $(85.73 \%$ of protection) in rats after seven days of postulcerative treatment compared with the controls. Other than that, the extract of emblic fruit also inhibited the growth of Staphylococcus aureus, Bacillus subtilis, Salmonella paratyphi, Shigella dysenteriae, and Candida albicans, although no inhibition of Escherichia coli growth was observed [41]. Also, the aqueous extract of emblic has shown the potential as an anticancer agent, where the extract inhibited the growth of human lung carcinoma and (A549) and human hepatocellular carcinoma (HepG2) cell lines [118]. Moreover, the emblic fruit powder demonstrated a significant chondroprotective effect based on an in vitro model of cartilage degradation in explant cultures of articular knee cartilages obtained from osteoarthritis patients [123].

Limited information on medicinal properties of selected Syzygium fruits ( $S$. jambos and S. malaccense) is available. The fruit of $S$. jambos (rose apple) has been traditionally used as an astringent and for brain and liver, as well as digestive problems [127]. Other than the use of Syzygium fruits as folk medicine, scientific research reported that the aqueous fruit extracts of $S$. jambos reduced the in vitro $\alpha$-glucosidase and $\alpha$-amylase inhibitory activities [128]. Other than these two Syzygium fruits, the fruit extracts of S. samarangense (samarang apple) were also as effective as antibiotics to inhibit microbial activities [129]. The fruit extract of S. cumini (Java plum) is also a potential antidiabetic agent [130].

Most of the literature only reported on the medical properties of different aerial parts (mainly leaves and bark) of underutilized plants instead of their fruits [131]. For example, the leaves of many plant species have antimicrobial activities. The methanolic extracts of $S$. jambos leaves were tested for antimicrobial activity, where the extracts inhibited the growth of some Gram-positive and Gram-negative bacteria [132]. Besides that, antimicrobial activities of the extracts of bark, leaves, and seeds of $S$. jambos have also been reported by Murugan et al. [133]. The leaves of S. malaccense (Malay apple) were reported to be useful for preventing inflammation [134]. Moreover, the extracts of different parts of Syzygium trees that have antidiabetic properties were documented in a review article [135].

Z. mauritiana (Indian jujube) is another fruit that is not well studied for its medicinal properties. The only therapeutic properties of the fruit are only available as reported in their traditional uses for treating abscesses, wounds, anodyne, and tonic, as well as styptic and purifying blood [87]. Until now, no human intervention study has been performed to determine the wound healing effect of $Z$. mauritiana fruit or its fruit extract. However, the leaves of $Z$. mauritiana were reported to significantly prevent leucopenia and noiseinduced enhancement of neutrophil function in Guinea pigs compared with diazepam, in which the Guinea pigs were subjected to $100 \mathrm{Db}$ industrial noise $(8-50 \mathrm{kHz})$ [136]. Antioxidant activities have also been determined for the fruits from two varieties of $Z$. mauritiana, and the $\mathrm{IC}_{50}$ values of the ethanolic extract of both varieties (Beri and Narikeli) were 72 and $250 \mu \mathrm{g} / \mathrm{mL}$, respectively [137]. The seed of $Z$. mauritiana has also been studied for its anticancer and antidiabetic potentials. The ethanolic extracts of $Z$. mauritiana seed were found to induce cancer cells death and significantly reduced tumor volume and tumor cell count in albino mice after 13 days of treatment with the extract (100-800 mg/kg BW) [138]. Besides that, the seed extract exhibited hypoglycemic activity, where administration of the extract (at a concentration of $800 \mathrm{mg} / \mathrm{kg} \mathrm{BW}$ ) reduced weight loss and mortality of alloxan-induced diabetic mice [139]. Alternatively, the root of $Z$. mauritiana has been traditionally used to treat ringworm by applying the root paste [140] and inhibition of microbial activities, such as Bacillus subtilis, Staphylococcus aureus, and Mycobacterium phlei [141].

On the contrary, some human intervention trials did not support the beneficial effects of antioxidant supplementation [142]. Although there was a dose-dependent relationship between antioxidative activity and antioxidant compound [143], an overdose of a particular bioactive compound may have prooxidative effect in the human body. Therefore, a moderate amount of antioxidant supplementation is suggested. Owing to lack of human-based scientific evidence, it is suggested that human intervention trials should be conducted in future studies to shed more light on the efficacy of potential bioactive components derived from these underutilized tropical fruits in any disease prevention. Although a part of these fruits have been studied for their medicinal properties, substantial scientific data is still lacking and the researches are still at a very preliminary stage. Future studies need to be performed for the fruits of B. macrocarpa, $B$. macrophylla, D. kutejensis, M. foetida, and S. jambos as there is no available data on these fruits until they are studied.

\section{Conclusions}

Southeast Asia, including Malaysia, consists of countries rich in plant biodiversity that possess more than a thousand types of fruit-bearing trees. Some of these fruits are already commercialized, but many are remaining underutilized. Nowadays, some of these trees are at least cultivated by the villagers or local farmers in the traditionally way for their fruits. Hence, identification of those indigenous tropical fruits with potential for commercial development can help researchers, farmers, or industry to see the opportunities from these native fruits. Indigenous tropical fruits are rich in phytochemicals, especially phenolic compounds, carotenoids, terpenes, and other terpenoids. Instead of providing the attractive colors of the fruits, phytochemicals also offer protective effects against chronic diseases, such 
as cardiovascular diseases, diabetes, and cancers. They are also responsible for the anti-inflammatory and antimicrobial effects, as well as other medicinal values of the fruits.

Scientifically, extra efforts are needed for studies emphasized on the beneficial health properties and toxicity effect of the fruit using animal-based experiments as well as human interventions to strengthen the scientific proof of their beneficial health properties. Studies on the toxicity effects of the fruits or their extracts should not also be neglected. Due to the variation in health benefits and bioactive phytochemicals in these fruits, attention should be given to study the efficacy of these fruits in combating diseases and later turning them into nutraceutical or basic ingredients for functional food. Bioactive compounds isolated from these fruits could also be used as nutraceutical and pharmaceutical ingredients. Primary screening of antioxidant properties and medicinal values for those indigenous tropical fruits without any scientific evidence is recommended to provide basic understanding for advance research. All the information is useful for the authorities concerned to promote the consumption of these fruits all around the world.

\section{Competing Interests}

The authors declare no conflict of interests.

\section{References}

[1] J. Kulip, "An ethnobotanical survey of medicinal and other useful plants of Muruts in Sabah, Malaysia," Telopea, vol. 10, no. 1, pp. 81-98, 2003.

[2] H. U. Kalsum and A. H. S. Mirfat, "Proximate composition of Malaysian underutilised fruits," Journal of Tropical Agriculture and Food Science, vol. 42, no. 1, pp. 63-72, 2014.

[3] H. E. Khoo, K. N. Prasad, K. W. Kong et al., "A review on underutilized tropical fruits in Malaysia," Guangxi Agricultural Sciences, vol. 41, no. 7, pp. 698-702, 2010.

[4] H.-E. Khoo, K. N. Prasad, K.-W. Kong, Y. Jiang, and A. Ismail, "Carotenoids and their isomers: color pigments in fruits and vegetables," Molecules, vol. 16, no. 2, pp. 1710-1738, 2011.

[5] L. Bravo, "Polyphenols: chemistry, dietary sources, metabolism, and nutritional significance," Nutrition Reviews, vol. 56, no. 11, pp. 317-333, 1998.

[6] A. Weizmann and Y. Mazur, "Steroids and triterpenoids of citrus fruit. II. Isolation of citrostadienol," The Journal of Organic Chemistry, vol. 23, no. 6, pp. 832-834, 1958.

[7] P. Scartezzini and E. Speroni, "Review on some plants of Indian traditional medicine with antioxidant activity," Journal of Ethnopharmacology, vol. 71, no. 1-2, pp. 23-43, 2000.

[8] C. Muthu, M. Ayyanar, N. Raja, and S. Ignacimuthu, "Medicinal plants used by traditional healers in Kancheepuram District of Tamil Nadu, India," Journal of Ethnobiology and Ethnomedicine, vol. 2, article 43, 2006.

[9] A. Rizvi, A. Mishra, A. A. Mahdi, M. Ahmad, and A. Basit, "Natural and herbal stress remedies: a review," International Journal of Pharmacognosy, vol. 2, no. 4, pp. 155-160, 2015.

[10] T. K. Lim, "Edible medicinal and non-medicinal plants," in Fruits, Springer Science+Business Media B.V., Dordrecht, Netherlands, 2012.
[11] H.-E. Khoo, K. N. Prasad, A. Ismail, and N. Mohd-Esa, "Carotenoids from Mangifera pajang and their antioxidant capacity," Molecules, vol. 15, no. 10, pp. 6699-6712, 2010.

[12] E. H. K. Ikram, K. H. Eng, A. M. M. Jalil et al., "Antioxidant capacity and total phenolic content of Malaysian underutilized fruits," Journal of Food Composition and Analysis, vol. 22, no. 5, pp. 388-393, 2009.

[13] S. W. Yan, R. Ramasamy, N. B. M. Alitheen, and A. Rahmat, "A comparative assessment of nutritional composition, total phenolic, total flavonoid, antioxidant capacity, and antioxidant vitamins of two types of Malaysian underutilized fruits (Averrhoa bilimbi and Averrhoa carambola)," International Journal of Food Properties, vol. 16, no. 6, pp. 1231-1244, 2013.

[14] A. Akeem, K. B. Mohamed, M. Z. Asmawi, and O. A. Sofiman, "Mutagenic and antimutagenic potentials of fruit juices of five medicinal plants in Allium cepa L.: possible influence of DPPH free radical scavengers," African Journal of Biotechnology, vol. 10, no. 50, pp. 10520-10529, 2011.

[15] S. F. Sulaiman and K. L. Ooi, "Antioxidant and $\alpha$-glucosidase inhibitory activities of 40 tropical juices from Malaysia and identification of phenolics from the bioactive fruit juices of Barringtonia racemosa and Phyllanthus acidus," Journal of Agricultural and Food Chemistry, vol. 62, no. 39, pp. 9576-9585, 2014.

[16] K. C. Wong and S. N. Wong, "Volatile constituents of Averrhoa bilimbi L. fruit," Journal of Essential Oil Research, vol. 7, no. 6, pp. 691-693, 1995.

[17] M. Hasanuzzaman, M. R. Ali, M. Hossain, S. Kuri, and M. S. Islam, "Evaluation of total phenolic content, free radical scavenging activity and phytochemical screening of different extracts of Averrhoa bilimbi (fruits)," International Current Pharmaceutical Journal, vol. 2, no. 4, pp. 92-96, 2013.

[18] D. R. Singh, S. Singh, K. M. Salim, and R. C. Srivastava, "Estimation of phytochemicals and antioxidant activity of underutilized fruits of Andaman Islands (India)," International Journal of Food Sciences and Nutrition, vol. 63, no. 4, pp. 446-452, 2012.

[19] J. A. Pino, R. Marbot, and A. Bello, "Volatile components of Averrhoa bilimbi L. fruit grown in Cuba," Journal of Essential Oil Research, vol. 16, no. 3, pp. 241-242, 2004.

[20] M. Bakar, N. Ahmad, F. Karim, and S. Saib, "Phytochemicals and antioxidative properties of Borneo indigenous liposu (Baccaurea lanceolata) and tampoi (Baccaurea macrocarpa) fruits," Antioxidants, vol. 3, no. 3, pp. 516-525, 2014.

[21] L. Y. Chew, K. N. Prasad, I. Amin, A. Azrina, and C. Y. Lau, "Nutritional composition and antioxidant properties of Canarium odontophyllum Miq. (dabai) fruits," Journal of Food Composition and Analysis, vol. 24, no. 4-5, pp. 670-677, 2011.

[22] A. Ismail, K. N. Prasad, L. Y. Chew, H. E. Khoo, K. W. Kong, and A. Azlan, "Antioxidant capacities of peel, pulp, and seed fractions of Canarium odontophyllum Miq. fruit," Journal of Biomedicine and Biotechnology, vol. 2010, Article ID 871379, 8 pages, 2010.

[23] L. Y. Chew, H. E. Khoo, I. Amin, A. Azrina, and C. Y. Lau, "Analysis of phenolic compounds of dabai (Canarium odontophyllum Miq.) fruits by high-performance liquid chromatography," Food Analytical Methods, vol. 5, no. 1, pp. 126-137, 2012.

[24] H. E. Khoo, A. Azlan, A. Ismail, and F. Abas, "Antioxidative properties of defatted dabai pulp and peel prepared by solid phase extraction," Molecules, vol. 17, no. 8, pp. 9754-9773, 2012.

[25] V. B. Hoe and K. H. Siong, "The nutritional value of indigenous fruits and vegetables in Sarawak," Asia Pacific Journal of Clinical Nutrition, vol. 8, no. 1, pp. 24-31, 1999. 
[26] I. Jantan, F. A. Jumuddin, F. C. Saputri, and K. Rahman, "Inhibitory effects of the extracts of Garcinia species on human low-density lipoprotein peroxidation and platelet aggregation in relation to their total phenolic contents," Journal of Medicinal Plants Research, vol. 5, no. 13, pp. 2699-2709, 2011.

[27] U. M. Acuña, Phenolic constituents from Garcinia intermedia and related species [M.S. thesis], The City University of New York, New York, NY, USA, 2011.

[28] U. M. Acuña, K. Dastmalchi, M. J. Basile, and E. J. Kennelly, "Quantitative high-performance liquid chromatography photo-diode array (HPLC-PDA) analysis of benzophenones and biflavonoids in eight Garcinia species," Journal of Food Composition and Analysis, vol. 25, no. 2, pp. 215-220, 2012.

[29] S. H. Ali Hassan, J. R. Fry, and M. F. Abu Bakar, "Phytochemicals content, antioxidant activity and acetylcholinesterase inhibition properties of indigenous Garcinia parvifolia fruit," BioMed Research International, vol. 2013, Article ID 138950, 7 pages, 2013.

[30] T. S. Tyug, M. H. Johar, and A. Ismail, "Antioxidant properties of fresh, powder, and fiber products of mango (Mangifera foetida) fruit," International Journal of Food Properties, vol. 13, no. 4, pp. 682-691, 2010.

[31] S. F. Sulaiman and K. L. Ooi, "Polyphenolic and vitamin C contents and antioxidant activities of aqueous extracts from mature-green and ripe fruit fleshes of Mangifera sp." Journal of Agricultural and Food Chemistry, vol. 60, no. 47, pp. 11832-11838, 2012.

[32] S. T. Tan and I. Amin, "Antioxidant properties (components and capacity) in fresh, powder and fibre products prepared from bacang (Mangifera foetida) fruits," Malaysian Journal of Nutrition, vol. 14, no. 2, pp. S8-S9, 2008.

[33] H. E. Khoo and A. Ismail, "Determination of daidzein and genistein contents in Mangifera fruit," Malaysian Journal of Nutrition, vol. 14, no. 2, pp. 189-198, 2008.

[34] M. F. Abu Bakar, M. Mohamed, A. Rahmat, and J. Fry, "Phytochemicals and antioxidant activity of different parts of bambangan (Mangifera pajang) and tarap (Artocarpus odoratissimus)," Food Chemistry, vol. 113, no. 2, pp. 479-483, 2009.

[35] K. N. Prasad, F. A. Hassan, B. Yang et al., "Response surface optimisation for the extraction of phenolic compounds and antioxidant capacities of underutilised Mangifera pajang Kosterm. peels," Food Chemistry, vol. 128, no. 4, pp. 1121-1127, 2011.

[36] M. Ibrahim, Nutrient composition, antioxidant properties and hypocholesterolemic effect of bambangan (Mangifera pajang Kostermans) pulp juice powder [Ph.D. thesis], Universiti Putra Malaysia, Selangor, Malaysia, 2010.

[37] D. Krishnaiah, T. Devi, A. Bono, and R. Sarbatly, "Studies on phytochemical constituents of six Malaysian medicinal plants," Journal of Medicinal Plants Research, vol. 3, no. 2, pp. 67-72, 2009.

[38] G. S. Kumar, H. Nayaka, S. M. Dharmesh, and P. V. Salimath, "Free and bound phenolic antioxidants in amla (Emblica officinalis) and turmeric (Curcuma longa)," Journal of Food Composition and Analysis, vol. 19, no. 5, pp. 446-452, 2006.

[39] S. J. Hossain, I. Tsujiyama, M. Takasugi, M. A. Islam, R. S. Biswas, and H. Aoshima, "Total phenolic content, antioxidative, anti-amylase, anti-glucosidase, and antihistamine release activities of Bangladeshi fruits," Food Science and Technology Research, vol. 14, no. 3, pp. 261-268, 2008.

[40] X. Liu, C. Cui, M. Zhao et al., "Identification of phenolics in the fruit of emblica (Phyllanthus emblica L.) and their antioxidant activities," Food Chemistry, vol. 109, no. 4, pp. 909-915, 2008.
[41] I. Ahmad and A. Z. Beg, "Antimicrobial and phytochemical studies on 45 Indian medicinal plants against multi-drug resistant human pathogens," Journal of Ethnopharmacology, vol. 74, no. 2, pp. 113-123, 2001.

[42] L. Sawant, N. Pandita, and B. Prabhakar, "Determination of gallic acid in Phyllanthus emblica Linn. dried fruit powder by HPTLC," Journal of Pharmacy and Bioallied Sciences, vol. 2, no. 2, pp. 105-108, 2010.

[43] K. A. Reynertson, H. Yang, B. Jiang, M. J. Basile, and E. J. Kennelly, "Quantitative analysis of antiradical phenolic constituents from fourteen edible Myrtaceae fruits," Food Chemistry, vol. 109, no. 4, pp. 883-890, 2008.

[44] S. Kondo, M. Kittikorn, and S. Kanlayanarat, "Preharvest antioxidant activities of tropical fruit and the effect of low temperature storage on antioxidants and jasmonates," Postharvest Biology and Technology, vol. 36, no. 3, pp. 309-318, 2005.

[45] J. Lako, V. C. Trenerry, M. Wahlqvist, N. Wattanapenpaiboon, S. Sotheeswaran, and R. Premier, "Phytochemical flavonols, carotenoids and the antioxidant properties of a wide selection of Fijian fruit, vegetables and other readily available foods," Food Chemistry, vol. 101, no. 4, pp. 1727-1741, 2007.

[46] S. Siriamornpun, N. Weerapreeyakul, and S. Barusrux, "Bioactive compounds and health implications are better for green jujube fruit than for ripe fruit," Journal of Functional Foods, vol. 12, pp. 246-255, 2015.

[47] E. M. Tanvir, R. Afroz, N. Karim et al., "Antioxidant and antibacterial activities of methanolic extract of BAU kul (Ziziphus mauritiana), an improved variety of fruit from Bangladesh," Journal of Food Biochemistry, vol. 39, no. 2, pp. 139-147, 2015.

[48] A. A. Memon, N. Memon, D. L. Luthria, A. A. Pitafi, and M. I. Bhanger, "Phenolic compounds and seed oil composition of Ziziphus mauritiana L. fruit," Polish Journal of Food and Nutrition Sciences, vol. 62, no. 1, pp. 15-21, 2012.

[49] H. A. Umaru, R. Adamu, D. Dahiru, and M. S. Nadro, "Levels of antinutritional factors in some wild edible fruits of Northern Nigeria," African Journal of Biotechnology, vol. 6, no. 16, pp. 1935-1938, 2007.

[50] InfoTANI, Buah-Buahan Nadir Di Malaysia, 2012, http://www .terengganu.gov.my/maxc2020/appshare/widget/mn_img/76682file/buah-buahan\%20nadir\%20di\%20malaysia.pdf.

[51] S. Subhadrabandhu, "Under-Utilized Tropical Fruits of Thailand," 2012, ftp://ftp.fao.org/docrep/fao/004/ab777e/ab777e00 .pdf.

[52] E. Singh, S. Sharma, A. Pareek, J. Dwivedi, S. Yadav, and S. Sharma, "Phytochemistry, traditional uses and cancer chemopreventive activity of Amla (Phyllanthus emblica): the sustainer," Journal of Applied Pharmaceutical Science, vol. 2, no. 1, pp. 176183, 2012.

[53] A. C. Dweck, "Natural ingredients for colouring and styling," International Journal of Cosmetic Science, vol. 24, no. 5, pp. 287302, 2002.

[54] H. E. Khoo, A. Ismail, N. Mohd-Esa, and S. Idris, "Carotenoid content of underutilized tropical fruits," Plant Foods for Human Nutrition, vol. 63, no. 4, pp. 170-175, 2008.

[55] S. H. Goh, C. H. Chuah, J. S. L. Mok, and E. Soepadmo, Malaysian Medicinal Plants for the Treatment of Cardiovascular Diseases, Pelanduk Publishing, Kuala Lumpur, Malaysia, 1995.

[56] S. Surialaga, D. Dhianawaty, A. Martiana, and A. S. Andreanus, "Antihypercholesterolemic effect of bilimbi (Averhoa bilimbi L.) fruit juice in hypercholesterolemic CFW Swiss Webster mice," Bandung Medical Journal, vol. 45, no. 2, pp. 125-129, 2013 (Indonesian). 
[57] G. J. Kapadia and G. S. Rao, "Antimicrobial and other biological effects of Garcinia plants used in food and herbal medicine," in Natural Antimicrobials in Food Safety and Quality, pp. 304-327, CABI, New York, NY, USA, 2011.

[58] S. Klaiklay, Chemical Constituents from the Twigs of Garcinia hombroniana, the Leaves of Garcinia prainiana and the roots of Clerodendrum petasites S. Moore [M.S. thesis], Price of Songkla University, Songkhla, Thailand, 2009.

[59] T. K. Lim, "Durio kutejensis," in Edible Medicinal and NonMedicinal Plants, pp. 559-562, Springer, Dordrecht, The Netherlands, 2012.

[60] F. H. Shakirin, A. Azlan, A. Ismail, Z. Amom, and L. Cheng Yuon, "Protective effect of pulp oil extracted from Canarium odontophyllum Miq. fruit on blood lipids, lipid peroxidation, and antioxidant status in healthy rabbits," Oxidative Medicine and Cellular Longevity, vol. 2012, Article ID 840973, 9 pages, 2012.

[61] A. Azlan, A. Ismail, M. Ibrahim, F. H. Shakirin, and H. E. Khoo, "Health-promoting properties of selected Malaysian underutilized fruits," in Proceeding of the 2nd International Symposium on Underutilized Plant Species, Kuala Lumpur, Malaysia, 2011.

[62] J. F. Morton, Fruits of Warm Climates, http://www.hort.purdue .edu/newcrop/morton.

[63] E.-S. Tee and C.-L. Lim, "Carotenoid composition and content of Malaysian vegetables and fruits by the AOAC and HPLC methods," Food Chemistry, vol. 41, no. 3, pp. 309-339, 1991.

[64] S. Anon, Nutritive Values of Thai Foods, Ministry of Public Health, Nonthaburi, Thailand, 1992.

[65] K. N. Prasad, L. Y. Chew, H. E. Khoo, B. Yang, A. Azlan, and A. Ismail, "Carotenoids and antioxidant capacities from Canarium odontophyllum Miq. fruit," Food Chemistry, vol. 124, no. 4, pp. 1549-1555, 2011.

[66] S. H. Ali-Hassan, I. R. Fry, and M. F. Abu-Bakar, "Antioxidative phytochemicals and anti-cholinesterase activity of native kembayau (Canarium odontophyllum) fruit of Sabah, Malaysian Borneo," Journal of Nutrition \& Food Sciences, vol. 4, no. 1, Article ID 1000249, 2013.

[67] E. S. Tee, M. I. Noor, M. N. Azudin, and K. Idris, Nutrient Composition of Malaysian Foods, Institute for Medical Research, Kuala Lumpur, Malaysia, 1997.

[68] K. Judprasong, S. Charoenkiatkul, P. Thiyajai, and M. Sukprasansap, "Nutrients and bioactive compounds of Thai indigenous fruits," Food Chemistry, vol. 140, no. 3, pp. 507-512, 2013.

[69] W. A. Whistler and C. R. Elevitch, Syzygium malaccense (Malay Apple), Species Profiles for Pacific Island Agroforestry, 2012, http://www.traditionaltree.org.

[70] G. S. Cheema, S. S. Bhat, and K. C. Naik, Commercial Fruits of India, Macmillan Publishers, Calcutta, India, 1954.

[71] A. H. Wu and M. C. Pike, "Phytoestrogen content in foods and their role in cancer," in Handbook of Antioxidants, Revised and Expanded, Marcel Dekker, New York, NY, USA, 2001.

[72] P. Shukla, P. Shukla, and B. Gopalkrishna, "Isolation and characterization of polyphenolic compound quercetin from Phyllanthus emblica," International Journal of Pharmaceutical Science Research, vol. 3, no. 5, pp. 1520-1522, 2012.

[73] Y. Boer, Antioxidant of kandis fruit peel [Garcinia parvifolia (Miq) Miq.] [M.S. thesis], University of Indonesia, Depok, Indonesia, 1999 (Indonesian).

[74] K. C. Wong, S. W. Wong, S. S. Siew, and D. Y. Tie, "Volatile constituents of the fruits of Lansium domesticum correa (Duku and Langsat) and Baccaurea motleyana (Muell. Arg.) Muell. Arg. (Rambai)," Flavour and Fragrance Journal, vol. 9, no. 6, pp. 319-324, 1994.

[75] K. C. Wong and H. K. Loi, "Volatile constituents of Bouea macrophylla Griff. fruit," Journal of Essential Oil Research, vol. 8, no. 1, pp. 99-100, 1996.

[76] V. Rukachaisirikul, A. Adair, P. Dampawan, W. C. Taylor, and P. C. Turner, "Lanostanes and friedolanostanes from the pericarp of Garcinia hombroniana," Phytochemistry, vol. 55, no. 2, pp. 183-188, 2000.

[77] K. C. Wong and C. H. Ong, "Volatile components of the fruits of bachang (Mangifera foetida Lour.) and kuini (Mangifera odorata Griff.)," Flavour and Fragrance Journal, vol. 8, no. 3, pp. 147-151, 1993.

[78] K. Panthong, R. Sompong, V. Rukachaisirikul, N. HutadilokTowatana, S. P. Voravuthikunchai, and J. Saising, "Two new triterpenes and a new coumaroyl glucoside from the twigs of Mangifera foetida Lour," Phytochemistry Letters, vol. 11, pp. 4348, 2015.

[79] K. C. Wong and S. S. Siew, "Volatile components of the fruits of bambangan (Mangifera panjang kostermans) and binjai (Mangifera caesia jack)," Flavour and Fragrance Journal, vol. 9, no. 4, pp. 173-178, 1994.

[80] X. Liu, M. Zhao, W. Luo, B. Yang, and Y. Jiang, "Identification of volatile components in Phyllanthus emblica L. and their antimicrobial activity," Journal of Medicinal Food, vol. 12, no. 2, pp. 423-428, 2009.

[81] K. C. Wong and F. Y. Lai, "Volatile constituents from the fruits of four Syzygium species grown in Malaysia," Flavour and Fragrance Journal, vol. 11, no. 1, pp. 61-66, 1996.

[82] G. Vernin, G. Vernin, J. Metzger, C. Roque, and J.-C. Pieribattesti, "Volatile constituents of the Jamrosa aroma Syzygium jambos L. Aston from Reunion Island," Journal of Essential Oil Research, vol. 3, no. 2, pp. 83-97, 1991.

[83] C. M. Guedes, A. B. Pinto, R. F. A. Moreira, and C. A. B. De Maria, "Study of the aroma compounds of rose apple (Syzygium jambos Alston) fruit from Brazil," European Food Research and Technology, vol. 219, no. 5, pp. 460-464, 2004.

[84] T. K. Lim, Edible Medicinal and Non-Medicinal Plants, vol. 1, Springer, Dordrecht, The Netherlands, 2012.

[85] S. Mohamad, N. M. Zin, H. A. Wahab et al., "Antituberculosis potential of some ethnobotanically selected Malaysian plants," Journal of Ethnopharmacology, vol. 133, no. 3, pp. 1021-1026, 2011.

[86] J. Morton, Fruits of Warm Climates, Florida Flair Books, Miami, Fla, USA, 1987

[87] S. K. Marwat, M. A. Khan et al., "Fruit plant species mentioned in the Holy Qura'n and Ahadith and their ethnomedicinal importance," American-Eurasian Journal of Agricultural Environmental Sciences, vol. 5, no. 2, pp. 284-295, 2009.

[88] M. Edelenbos, L. P. Christensen, and K. Grevsen, "HPLC determination of chlorophyll and carotenoid pigments in processed green pea cultivars (Pisum sativum L.)," Journal of Agricultural and Food Chemistry, vol. 49, no. 10, pp. 4768-4774, 2001.

[89] I. Fichan, C. Larroche, and J. B. Gros, "Water solubility, vapor pressure, and activity coefficients of terpenes and terpenoids," Journal of Chemical and Engineering Data, vol. 44, no. 1, pp. 5662, 1999.

[90] M. S. Kumar, S. Kumar, and B. Raja, "Antihypertensive and antioxidant potential of borneol-a natural terpene in LNAME-induced hypertensive rats," International Journal of 
Pharmaceutical \& Biology Archive, vol. 1, no. 3, pp. 271-279, 2010.

[91] A. V. Rao and D. M. Gurfinkel, "The bioactivity of saponins: triterpenoid and steroidal glycosides," Drug Metabolism and Drug Interactions, vol. 17, no. 1-4, pp. 211-235, 2000.

[92] B. M. Fraga, "Natural sesquiterpenoids," Natural Product Reports, vol. 19, no. 5, pp. 650-672, 2002.

[93] J. D. Connolly and R. A. Hill, "Triterpenoids," Natural Product Reports, vol. 25, no. 4, pp. 794-830, 2008.

[94] G. J. E. Nychas, "Natural antimicrobials from plants," in New Methods of Food Preservation, pp. 58-89, Chapman \& Hall, New York, NY, USA, 1995.

[95] S. H. Thilakarathna and H. P. Vasantha Rupasinghe, "Antiatherosclerotic effects of fruit bioactive compounds: a review of current scientific evidence," Canadian Journal of Plant Science, vol. 92, no. 3, pp. 407-419, 2012.

[96] S. Ambili, A. Subramoniam, and N. S. Nagarajan, "Studies on the antihyperlipidemic properties of Averrhoa bilimbi fruit in rats," Planta Medica, vol. 75, no. 1, pp. 55-58, 2009.

[97] B. K. H. Tan, P. Fu, P. W. Chow, and A. Hsu, "Effects of A. bilimbi on blood sugar and food intake in streptozotocin induced diabetic rats," Phytomedicine, vol. 3, pp. 271-272, 1996.

[98] N. H. A. Wahab, M. E. A. Wahid, M. Taib, W. Z. W. M. Zain, and S. A. Anwar, "Phytochemical screening and antimicrobial efficacy of extracts from Averrhoa bilimbi (Oxalidaceace) fruits against human pathogenic bacteria," Pharmacognosy Journal, vol. 1, no. 1, pp. 64-66, 2009.

[99] M. H. Nurulhuda, A. Azlan, A. Ismail, Z. Amom, and F. H. Shakirin, "Sibu olive inhibits artherosclerosis by cholesterol lowering effect in cholesterol fed-rabbit," in Proceeding of the 4th International Conference on Biomedical Engineering, pp. 141144, Ho Chi Minh City, Vietnam, 2013.

[100] M. H. Nurulhuda, A. Azlan, A. Ismail, Z. Amom, and F. H. Shakirin, "Cholesterol-lowering and atherosclerosis inhibitory effect of Sibu olive in cholesterol fed-rabbit," Asian Journal of Biochemistry, vol. 7, no. 2, pp. 80-89, 2012.

[101] J. Leverett, A. Chandra, J. Rana, D. J. Fast, S. R. Missler, and D. M. Flower, "Extracts of durian fruit for use in skin care compositions," US Patent Publication Number US20070042064 A1, 2005.

[102] S. Mohamed, Z. Hassan, and N. A. Hamid, "Antimicrobial activity of some tropical fruit wastes (guava, starfruit, banana, papaya, passionfruit, langsat, duku, rambutan and rambai)," Pertanika Journal of Tropical Agricultural Science, vol. 17, no. 3, pp. 219-227, 1994.

[103] T.-J. S. A. Tajudin, N. Mat, A. B. Siti-Aishah, A. A. M. Yusran, A. Alwi, and A. M. Ali, "Cytotoxicity, antiproliferative effects, and apoptosis induction of methanolic extract of Cynometra cauliflora Linn. whole fruit on human promyelocytic leukemia HL-60 cells," Evidence-Based Complementary and Alternative Medicine, vol. 2012, Article ID 127373, 6 pages, 2012.

[104] M. Hemshekhar, K. Sunitha, M. S. Santhosh et al., "An overview on genus Garcinia: phytochemical and therapeutical aspects," Phytochemistry Reviews, vol. 10, no. 3, pp. 325-351, 2011.

[105] I. Jantan, I. A. A. Rafi, and J. Jalil, "Platelet-activating factor (PAF) receptor-binding antagonist activity of Malaysian medicinal plants," Phytomedicine, vol. 12, no. 1-2, pp. 88-92, 2005.

[106] M. F. Abu Bakar, M. Mohamad, A. Rahmat, S. A. Burr, and J. R. Fry, "Cytotoxicity, cell cycle arrest, and apoptosis in breast cancer cell lines exposed to an extract of the seed kernel of Mangifera pajang (bambangan)," Food and Chemical Toxicology, vol. 48, no. 6, pp. 1688-1697, 2010.
[107] M. F. Abu Bakar, M. Mohamed, A. Rahmat, S. A. Burr, and J. R. Fry, "Cellular assessment of the extract of bambangan (Mangifera pajang) as a potential cytoprotective agent for the human hepatocellular HepG2 cell line," Food Chemistry, vol. 136, no. 1, pp. 18-25, 2013.

[108] A. Ismail, M. Ibrahim, A. Azlan, and A. Hamid, "Effects of juice powder prepared from underutilised Mangifera pajang fruit on lipid profiles and antioxidant biomarkers in human subjects," in Proceedings of the 11th ASEAN Food Conference, Bandar Seri Begawan, Brunei Darussalam, 2009.

[109] L. Mosca, M. Rubenfire, C. Mandel et al., "Antioxidant nutrient supplementation reduces the susceptibility of low density lipoprotein to oxidation in patients with coronary artery disease," Journal of the American College of Cardiology, vol. 30, no. 2, pp. 392-399, 1997.

[110] P. W. Grosvenor, A. Supriono, and D. O. Gray, "Medicinal plants from Riau Province, Sumatra, Indonesia. Part 2: antibacterial and antifungal activity," Journal of Ethnopharmacology, vol. 45, no. 2, pp. 97-111, 1995.

[111] B. Halliwell, "Commentary oxidative stress, nutrition and health. Experimental strategies for optimization of nutritional antioxidant intake in humans," Free Radical Research, vol. 25, no. 1, pp. 57-74, 1996.

[112] R. N. Chopra, S. L. Nayer, and I. C. Chopra, Glossary of Indian Medicinal Plant, Council of Scientific and Industrial Research, New Delhi, India, 1992.

[113] M. Krishnaveni and S. Mirunalini, "Therapeutic potential of Phyllanthus emblica (AMLA): the ayurvedic wonder," Journal of Basic and Clinical Physiology and Pharmacology, vol. 21, no. 1, pp. 93-105, 2010.

[114] M. N. W. Norhana, A. M. N. Azman, S. E. Poole, H. C. Deeth, and G. A. Dykes, "Effects of bilimbi (Averrhoa bilimbi L.) and tamarind (Tamarindus indica L.) juice on Listeria monocytogenes Scott A and Salmonella Typhimurium ATCC 14028 and the sensory properties of raw shrimps," International Journal of Food Microbiology, vol. 136, no. 1, pp. 88-94, 2009.

[115] E. T. Arung, W. Suwinarti, M. Hendra et al., "Determination of antioxidant and anti-melanogenesis activities of Indonesian Lai, Durio kutejensis [Bombacaceae (Hassk) Becc] fruit extract," Tropical Journal of Pharmaceutical Research, vol. 14, no. 1, pp. 41-46, 2015.

[116] J.-H. Sim, C.-H. Khoo, L.-H. Lee, and Y.-K. Cheah, "Molecular diversity of fungal endophytes isolated from Garcinia mangostana and Garcinia parvifolia," Journal of Microbiology and Biotechnology, vol. 20, no. 4, pp. 651-658, 2010.

[117] M. F. A. Bakar, M. Mohamed, A. Rahmat, S. A. Burr, and J. R. Fry, "Cytotoxicity and polyphenol diversity in selected parts of Mangifera pajang and Artocarpus odoratissimus fruits," Nutrition and Food Science, vol. 40, no. 1, pp. 29-38, 2010.

[118] S. Bhattacharya, S. R. Chaudhuri, S. Chattopadhyay, and S. K. Bandyopadhyay, "Healing properties of some Indian medicinal plants against indomethacin-induced gastric ulceration of rats," Journal of Clinical Biochemistry and Nutrition, vol. 41, no. 2, pp. 106-114, 2007.

[119] H. Dhir, A. K. Roy, A. Sharma, and G. Talukder, "Modification of clastogenicity of lead and aluminium in mouse bone marrow cells by dietary ingestion of Phyllanthus emblica fruit extract," Mutation Research/Genetic Toxicology, vol. 241, no. 3, pp. 305312, 1990

[120] W. Luo, M. Zhao, B. Yang, J. Ren, G. Shen, and G. Rao, "Antioxidant and antiproliferative capacities of phenolics purified from 
Phyllanthus emblica L. fruit," Food Chemistry, vol. 126, no. 1, pp. 277-282, 2011.

[121] K. Pinmai, S. Chunlaratthanabhorn, C. Ngamkitidechakul, N. Soonthornchareon, and C. Hahnvajanawong, "Synergistic growth inhibitory effects of Phyllanthus emblica and Terminalia bellerica extracts with conventional cytotoxic agents: doxorubicin and cisplatin against human hepatocellular carcinoma and lung cancer cells," World Journal of Gastroenterology, vol. 14, no. 10, pp. 1491-1497, 2008.

[122] S. Pientaweeratch, V. Panapisal, and A. Tansirikongkol, "Antioxidant, anti-collagenase and anti-elastase activities of Phyllanthus emblica, Manilkara zapota and silymarin: an in vitro comparative study for anti-aging applications," Pharmaceutical Biology, vol. 24, pp. 1-8, 2016.

[123] V. N. Sumantran, A. Kulkarni, R. Chandwaskar et al., "Chondroprotective potential of fruit extracts of Phyllanthus emblica in osteoarthritis," Evidence-Based Complementary and Alternative Medicine, vol. 5, no. 3, pp. 329-335, 2008.

[124] H. Sakander, B. Akhilesh, and A. R. Koteshwara, "Evaluation of antifungal potential of selected medicinal plants against human pathogenic fungi," International Journal of Green Pharmacy, vol. 9, no. 2, pp. 110-117, 2015.

[125] A. D. Dalee, S. Mukhurah, K. Sali, N. Hayeeyusoh, Z. Hajiwangoh, and P. Salaeh, "Antimicrobial substances from endophytic fungi in tamarind (Tamarindus indica Linn), malay apple (Eugenia malaccensis, Linn), rambutan (Nephelium lappaceum), and Indian mulberry (Morinda citrifolia, Linn)," in Proceeding of the International Conference on Research, Implementation and Education of Mathematics and Sciences, 2015.

[126] M. Goyal, D. Sasmal, and B. P. Nagori, "Review on ethnomedicinal uses, pharmacological activity and phytochemical constituents of Ziziphus mauritiana (Z. jujuba Lam., non Mill)," Spatula DD, vol. 2, no. 2, pp. 107-116, 2012.

[127] K. A. Reynertson, Phytochemical analysis of bioactive constituents from edible myrtaceae fruits [M.S. thesis], The City University of New York, New York, NY, USA, 2007.

[128] S. Das, S. Das, and B. De, "In vitro inhibition of key enzymes related to diabetes by the aqueous extracts of some fruits of West Bengal, India," Current Nutrition and Food Science, vol. 8, no. 1, pp. 19-24, 2012.

[129] K. V. Ratnam and R. R. V. Raju, "In vitro antimicrobial screening of the fruit extracts of two Syzygium species (Myrtaceae)," Advances in Biological Research, vol. 2, no. 1-2, pp. 17-20, 2008.

[130] A. Kumar, R. Ilavarasan, T. Jayachandran et al., "Anti-diabetic activity of Syzygium cumini and its isolated compound against streptozotocin-induced diabetic rats," Journal of Medicinal Plants Research, vol. 2, no. 9, pp. 246-249, 2008.

[131] L.-L. Yang, C.-Y. Lee, and K.-Y. Yen, "Induction of apoptosis by hydrolyzable tannins from Eugenia jambos L. on human leukemia cells," Cancer Letters, vol. 157, no. 1, pp. 65-75, 2000.

[132] S. Mohanty and I. E. Cock, "Bioactivity of Syzygium jambos methanolic extracts: antibacterial activity and toxicity," Pharmacognosy Research, vol. 2, no. 1, pp. 4-9, 2010.

[133] S. Murugan, P. U. Devi, N. K. Parameswari, and K. R. Mani, "Antimicrobial activity of Syzygium jambos against selected human pathogens," International Journal of Pharmacy and Pharmaceutical Sciences, vol. 3, no. 2, pp. 44-47, 2011.

[134] P. A. Cox, "Saving the ethnopharmacological heritage of Samoa," Journal of Ethnopharmacology, vol. 38, no. 2-3, pp. 181$188,1993$.

[135] E. R. H. S. S. Ediriweera and W. D. Ratnasooriya, "A review on herbs used in treatment of diabetes mellitus by Sri Langkan ayurvedic and traditional physicians," $A Y U$ (An International Quarterly Journal of Research in Ayurveda), vol. 30, no. 4, pp. 373-391, 2009.

[136] B. Vakharia, M. Adhvaryu, and N. Reddy, "Evaluation of adaptogenic potential of Curcuma longa and Zizyphus mauritiana against acute noise stress induced changes in guinea pigs," The Journal of Alternative and Complementary Medicine, vol. 20, no. 5, pp. A37-A37, 2014.

[137] R. S. K. Nimbalkar and S. K. Rajurkar, "Antioxidant activities of Zizyphus mauritiana Lam. (Rhamnaceae)," Biological Forum, vol. 1, no. 2, pp. 98-101, 2009.

[138] T. Mishra, M. Khullar, and A. Bhatia, "Anticancer potential of aqueous ethanol seed extract of Ziziphus mauritiana against cancer cell lines and Ehrlich ascites carcinoma," Evidence-Based Complementary and Alternative Medicine, vol. 2011, Article ID 765029, 11 pages, 2011.

[139] A. Bhatia and T. Mishra, "Hypoglycemic activity of Ziziphus mauritiana aqueous ethanol seed extract in alloxan-induced diabetic mice," Pharmaceutical Biology, vol. 48, no. 6, pp. 604610, 2010.

[140] R. S. L. Taylor, N. P. Manandhar, J. B. Hudson, and G. H. N. Towers, "Antiviral activities of Nepalese medicinal plants," Journal of Ethnopharmacology, vol. 52, no. 3, pp. 157-163, 1996.

[141] R. S. Taylor, N. P. Manandhar, and G. H. N. Towers, "Screening of selected medicinal plants of Nepal for antimicrobial activities," Journal of Ethnopharmacology, vol. 46, no. 3, pp. 153-159, 1995.

[142] R. Blomhoff, "Dietary antioxidants and cardiovascular disease," Current Opinion in Lipidology, vol. 16, no. 1, pp. 47-54, 2005.

[143] L.-S. Lai, S.-T. Chou, and W.-W. Chao, "Studies on the antioxidative activities of Hsian-tsao (Mesona procumbens Hemsl) leaf gum," Journal of Agricultural and Food Chemistry, vol. 49, no. 2, pp. 963-968, 2001. 


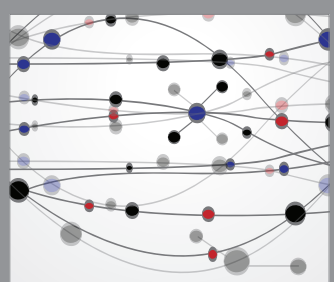

The Scientific World Journal
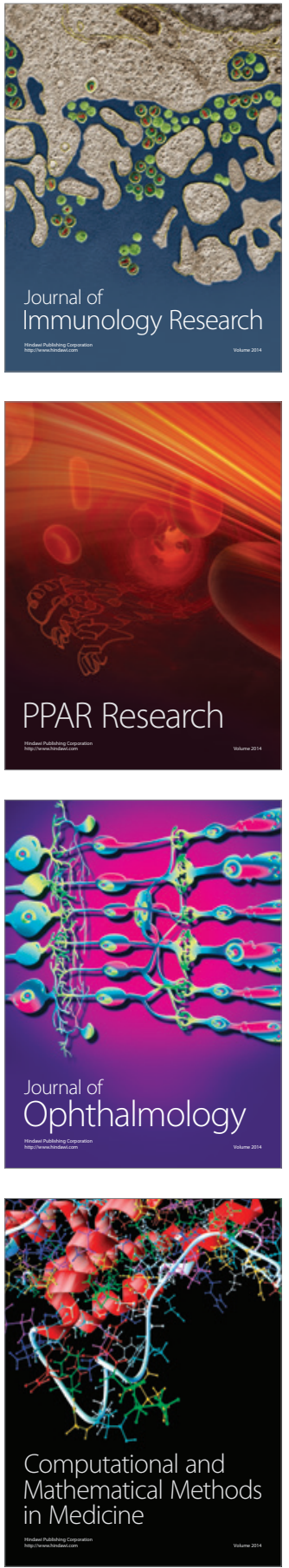

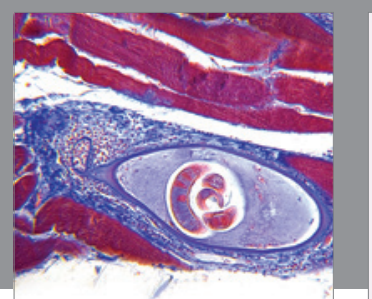

Gastroenterology Research and Practice

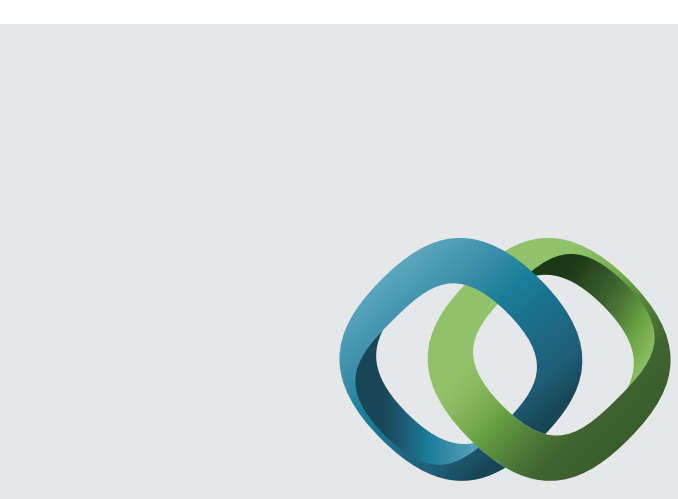

\section{Hindawi}

Submit your manuscripts at

http://www.hindawi.com
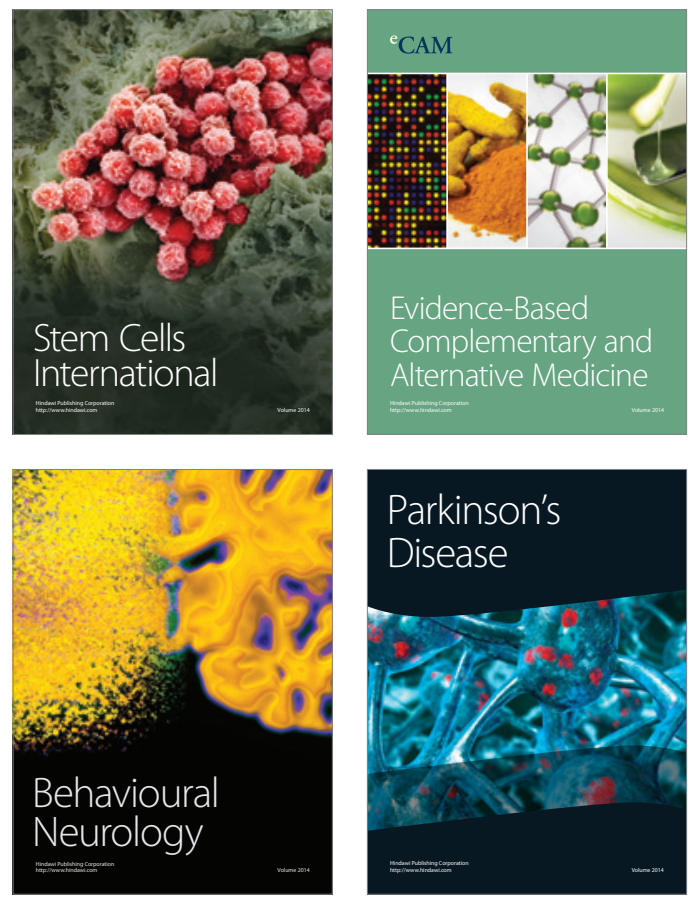
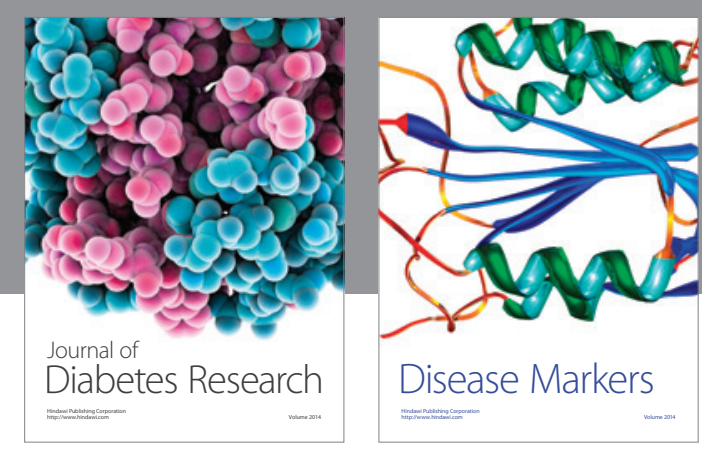

Disease Markers
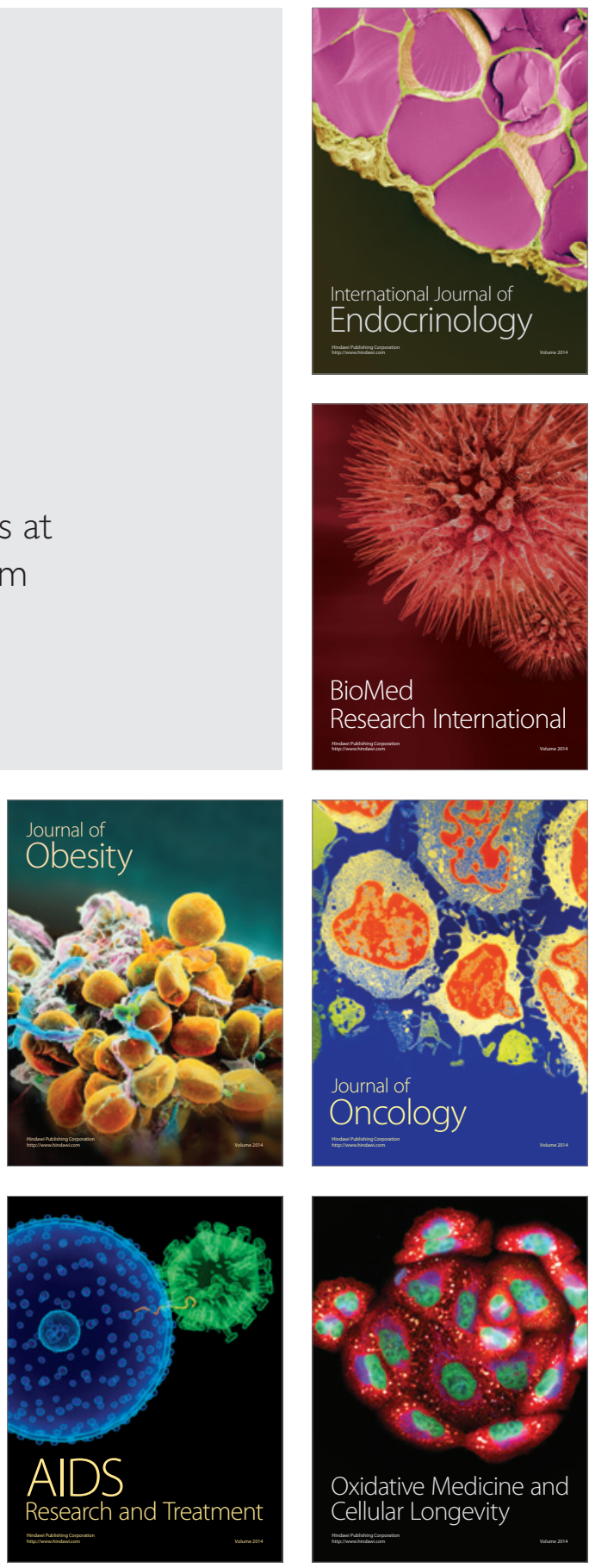